\title{
[7]
}

\section{Coping with Permanent Austerity Welfare State Restructuring in Affluent Democracies}

\author{
Paul Pierson
}

THE welfare states of the affluent democracies now stand at the centre of political discussion and social conflict. Analysts frequently portray these conflicts as fundamental struggles between supporters and opponents of the basic principles of the post-war social contract. They often emphasize that the politics of social policy are played out against the backdrop of a transformed global economy that has undercut the social and economic foundations of the welfare state. While containing elements of truth, such portrayals distort crucial characteristics of the contemporary politics of the welfare state. Changes in the global economy are important, but it is primarily social and economic transformations occurring within affluent democracies that produce pressures on mature welfare states. At the same time, support for the welfare state remains widespread almost everywhere. In most countries, there is little sign that the basic commitments to a mixed economy of welfare face a fundamental political challenge. Nor is there much evidence of convergence towards some neoliberal orthodoxy.

Yet the chapters in this volume have also stressed that welfare states are undergoing quite significant changes. In this conclusion, I argue that the contemporary politics of the welfare state take shape against a backdrop of both intense pressures for austerity and enduring popularity. In this context, even strong supporters of the welfare state may come to acknowledge the need for adjustment, and even severe critics may need to accept the political realities of continuing popular enthusiasm for social provision. Thus, in most of the affluent democracies, the politics of social policy centre on the renegotiation, restructuring, and modernization of the terms of the postwar social contract rather than its dismantling. The crucial issue is whether particular national settings facilitate the emergence of such a centrist reform effort, and if so, on what terms.

Thanks to Andrew Karch and Effi Tomaras for research assistance. I have benefited from many conversations with participants in the New Politics project and the European Forum at the EUI. I owe special thanks to John Myles and Ann Orloff, although I suppose it would be unfair to hold them responsible for the end result. 


\section{Coping with Permanent Austerity}

The argument proceeds in three stages. In the first, I outline a basic framework for studying the politics of reform in a context of permanent austerity. In the second, I discuss two complications: the need to incorporate different dimensions of social policy reform and the need to recognize three quite distinct configurations of welfare state politics among the affluent democracies. In the third, I apply these arguments to analyse the politics of restructuring in the liberal, social democratic, and conservative 'worlds' of welfare capitalism.

\section{AN INITIAL FRAMEWORK FOR STUDYING THE POLITICS OF PERMANENT AUSTERITY ${ }^{1}$}

Despite some disagreement concerning the main sources of pressure on mature welfare states, the chapters in Part I all conclude that the welfare state now faces a context of essentially permanent austerity. Changes in the global economy, the sharp slowdown in economic growth, the maturation of governmental commitments, and population ageing all generate considerable fiscal stress. There is little reason to expect these pressures to diminish over the next few decades. If anything, they are likely to intensify.

Underlining the severe pressures confronting mature welfare states does not, however, imply that the expected result is a collapse or radical retrenchment of national welfare states. Major policy reform is a political process, dependent on the mobilization of political resources sufficient to overcome organized opponents and other barriers to change. The welfare state's opponents have found it very difficult to generate and sustain this kind of political mobilization.

I have developed this argument elsewhere (Pierson 1994, 1996) and present only a condensed version here. The sources of the welfare state's political strength are diverse, but are of two basic types: the electoral incentives assosiared with programmes which retain broad and deep popular support and the institutional 'stickiness' which further constrains the possibilities for policy reform. Together, these features have created tremendous resilience in the face of two decades of welfare state 'crisis' (Stephens, Huber, and Ray 1999).

\section{Electoral Incentives}

In market democracies, voters play a crucial role. Implementing and susaining policy reforms over time generally requires electoral vindication. Voters, however, remain strongly attached to the welfare state. The broad public

\footnotetext{
1 This section draws on material presented in Pierson 1998.
} 


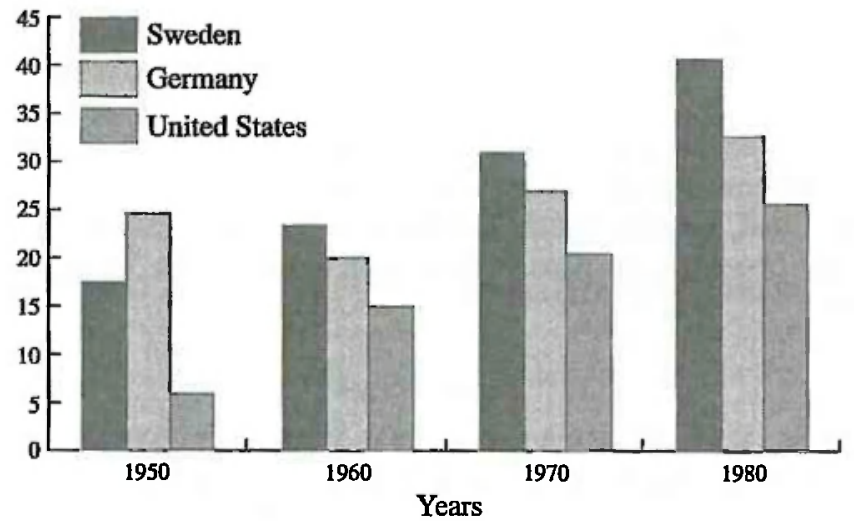

FIG. 13.1. Welfare state clienteles as a percentage of the electorate, 1950-80 Sources: Welfare state clienteles include public social welfare employment (excluding education) as well as recipients of pensions, disability, social assistance, and unemployment benefits. All welfare state clientele date comes from tables 4.5, 4.16, 6.3, 6.10, 7.4, and 7.14 in Richard Rose. Public Employment in Western Nations (Cambridge: Cambridge University Press, 1985). Electoral data comes from Thomas T. Mackie and Richard Rose, The International Almanac of Electoral History (London: Macmillan, 1991), fully revised, third edition. All American welfare state data covers 1952,1962, 1972, and 1982. American electoral data covers 1952, 1964, 1972, and 1984. German electoral data covers 1949, 1961, 1969, and 1980. Swedish electoral data covers 1952, 1960,1970, and 1979.

support consistently revealed in polls stems from several sources. As the welfare state has expanded, so has the size of its constituencies. As Peter Flora has noted, 'including recipients of [pensions,] unemployment benefits and social assistance and the persons employed in education, health and the social services, in many countries today almost $1 / 2$ of the electorate receive transfer or work income from the welfare state' (Flora 1989: 154). Figure 13.1 and Table 13.1 offer a very rough indication of the political transformation associated with welfare state expansion. Figure 13.1 shows the dramatic impact of welfare state growth from roughly 1950 to 1980 . It tracks a conservative measure of welfare state employment, plus a very conservative estimate of transfer recipients, as a share of the total electorate for three representative countries. From the beginning of the post-war expansion (1960) to the rough end of the maturation period (1980) these ratios increase markedly in all cases. Table 13.1 provides snapshots from the mid-1990s for the same countries. Again measured on a conservative basis, one can see both that the core constituencies of the welfare state are very large, and that there are marked variations across countries.

These crude indicators considerably underestimate the scale of the welfare state's reach into contemporary political life. Many voters who do not 
Coping with Permanent Austerity

TABLE 13.1. Major welfare state clienteles in three countries, 1995

\begin{tabular}{lrrr}
\hline & Sweden & Germany & United States \\
\hline Pensions & $1,584,304$ & $21,630,000$ & $43,388,000$ \\
Disability & 408,576 & $1,180,000$ & $5,857,656$ \\
Unemployment & 37,734 & $1,990,000$ & $7,900,000$ \\
Social assistance & 474,159 & $2,080,000$ & $4,869,000$ \\
Public welfare employment & $1,245,800$ & $1,590,000$ & $2,540,000$ \\
ToTaL & $3,750,573$ & $28,470,000$ & $64,554,656$ \\
Electorate & $6,551,591$ & $56,090,000$ & $196,089,000$ \\
Percentage & 57.25 & 50.76 & 32.92 \\
\hline
\end{tabular}

Sources: Sweden-Statistiska Centralbyran, Statistisk Arsbok '97 (1997). Germany-Statistiches Bundesamt, Statistiches Jahrbuch fur die Bundesrepublic Deutschland (1998). United StatesCommittee on Ways and Means, 1996 Green Book (1996). German welfare state clientele data and American electorate data cover 1996.

currently receive social benefits expect that they may at some point in their lives. Or they may be in the same household with someone who receives benefits from, or is employed by, the welfare state. In most countries, universal programmes, especially health care but also other social services, generate widespread support. Furthermore, the welfare state retains considerable legitimacy as a source of social stability and guarantor of basic rights of citizenship. Popular support generally appears to extend well beyond the confines of narrow economic self-interest.

Support for the welfare state is intense as well as broad. Intensity of preference matters because it is associated with higher rates of political mobilization and with voters' actual choices at election time. The intensity of support for the welfare state stems from two factors. First, while the benefits of retrenchment for welfare state opponents are generally diffuse and often uncertain, the large core constituencies for the welfare state have a concentrated interest in the maintenance of social provision. Huge segments of the electorates of advanced industrial societies rely on the welfare state for a large share of their income. It is one of the few basic axioms of political science that concentrated interests will generally be advantaged over diffuse ones.

The second source of intensity stems from the fact that welfare state supporters are in the position of fighting to sustain already existing benefits. Students of electoral behaviour and political psychology have found that voters exhibit a 'negativity bias'- they react more intensely to potential losses than to commensurate potential gains. Thus, the welfare state's electoral base is not only enormous, but primed to punish politicians for unpopular initiatives. 


\section{Institutional 'Stickiness'}

Those seeking policy reform must confront not only the potential opposition of voters and programme beneficiaries but the stickiness of existing policy arrangements. By stickiness $I$ have in mind two features of developed polities that reinforce the electoral obstacles to radical reform: formal and informal institutional 'veto points', and 'path dependent' processes, which in many cases tend to lock existing policy arrangements into place. Each of these characteristics pushes reform agendas in the direction of incremental adjustments to existing arrangements.

The basic point about veto points is straightforward and clearly spelled out in Bonoli's contribution to this volume (see more broadly Scharpf 1986; Tsebelis 1995). Most political systems make policy reform dependent on more than a simple 51 per cent majority, allowing minorities (including in some cases quite small ones) opportunities to block reforms. Examples of such institutional arrangements include federalism, a strong judiciary, bicameralism, use of referenda, requirements of super-majorities, and coalition-based governments. $^{2}$ Difficult as it is to create a majority coalition in favour of restructuring the welfare state, even that may not be enough. The multiplication of veto points can hamstring efforts at policy change, frustrating even an ambitious and aggressive reform coalition such as the Republican congressional majority in the United States after 1994, or an enduring conservative coalition such as the one governing Germany from 1982 to 1998.

A second major source of stickiness, path dependence, is more complex. Because path dependence is often invoked as an explanation without further explication, some elaboration is necessary. ${ }^{3}$ Certain courses of political development, once initiated, are hard to reverse. It is not just that institutional veto points may make a reversal of course difficult. Individual and organizational adaptations to previous arrangements may also make reversal unattractive.

Recent work on path dependence has emphasized the ways in which initial social outcomes concerning institutional, organizational, or policy designeven suboptimal ones-can become self-reinforcing over time (Krasner 1989; North 1990). These initial choices encourage the emergence of elaborate social and economic networks, greatly increasing the cost of adopting oncepossible alternatives and therefore inhibiting exit. Major social arrangements have major social consequences. Individuals make important commitments in response to government actions. These commitments, in turn, may vastl increase the disruption caused by institutional reforms, effectively 'locking-

2 Veto points may also be policy-specific. The Canada Pension Plan (CPP), for example cannot be reformed without a large super-majority among provincial governments.

${ }^{3}$ See also the discussions in the chapters by Myles and Pierson and Wood. A more detailed discussion can be found in Pierson (2000). 


\section{Coping with Permanent Austerity}

in' previous decisions. As a result, as Douglass North has emphasized, change in well-institutionalized polities is typically incremental.

Research on technological change has revealed some of the circumstances conducive to path dependence (David 1985; Arthur 1994). The crucial factor is the presence of increasing returns, which encourages actors to focus on a single alternative and to continue movement down a particular path once initial steps are taken. Large set-up or fixed costs are likely to create increasing returns to further investment in a given technology, providing individuals with a strong incentive to identify and stick with a single option. Substantial learning effects connected to the operation of complex systems provide an additional source of increasing returns. Coordination effects (or network externalities) occur when the individual receives increased benefits from a particular activity if others also adopt the same option. Finally, adaptive expectations occur when individuals feel a need to 'pick the right horse' because options that fail to win broad acceptance will have drawbacks later on. Under these conditions, individual expectations about usage patterns may become self-fulfilling.

As North has argued, all of these arguments can be extended from studies of technological change to other social processes, particularly to the development of institutions. In contexts of complex social interdependence, new institutions or policies often entail high fixed or start-up costs, may involve considerable learning effects, and generate coordination effects and adaptive expectations. Established institutions generate powerful inducements that reinforce their own stability and further development. 'In short', North concludes, "the interdependent web of an institutional matrix produces massive increasing returns', making path dependence a common feature of institutional evolution (North 1990: 95).

Over time, as social actors make commitments based on existing institutions, the cost of 'exit' rises. Learning from past events may lead actors to act differently in launching new initiatives. Recapturing ground in previously institutionalized fields of activity, however, will often be quite difficult. Actors do not inherit a blank slate that they can remake at will when their preferences change or the balance of power shifts. Instead, they find that the dead weight of previous institutional choices seriously limits their room to manoeuvre.

Because this point is so often misconstrued, it should be stressed that the claim is not that path dependence 'freezes' existing arrangements in Jlace. Change continues, but it is bounded change. North (1990: 98-9) ummarizes the key point well: At every step along the way there [are] choices-political and economic-that provide... real alternatives. Path d.pendence is a way to narrow conceptually the choice set and link decision raking through time. It is not a story of inevitability in which the past rvatly predicts the future.' 
One of the major themes of this volume is that contemporary welfare states, and the politics that surround them, strongly reflect these path-dependent effects. As Myles and Pierson argue, old-age pension systems provide a powerful example. Most countries operate pensions on a pay-as-you-go basis: current workers pay 'contributions' that finance the previous generation's retirement. Once they have been in place for a long time, pay-as-you-go systems may face incremental cutbacks and adjustments, but they are highly resistant to radical reform. Shifting to private, funded arrangements would place an untenable burden on current workers, requiring them to finance the previous generation's retirement while simultaneously saving for their own. Even partial privatization has generally proven possible only in the relatively few countries lacking extensive and mature pay-as-you-go systems.

Similar if less severe path-dependent effects are likely in areas of social policy where complex sets of institutions and organizations have 'co-evolved' over extended periods. The chapters by Giaimo, Manow, and Wood all emphasize this type of dynamic. In health care provision and many aspects of labour market systems, social actors need to coordinate their activities and they invest resources in line with the incentive structures of their existing environment (see also Giaimo and Manow 1999; Hacker 1998). This probably helps to explain why employers, for instance, have often been more halfhearted and internally divided over policy reform than many theories of political economy might have anticipated (Thelen 1999).

Both the popularity of the welfare state and the prevalence of 'stickiness' must be at the centre of an investigation of restructuring. The essential point is that welfare states face severe strains and they retain deep reservoirs of political support. For political analysts, the central question can thus be put as follows: What happens when the irresistible forces of post-industrialism meet the immovable object of the welfare state? Acknowledging the strength of both sides of this collision generates several implications for investigating the politics of reform.

There are strong grounds for scepticism about the prospect for any radical revision of the welfare state in most countries. Almost nowhere have politicians been able to assemble and sustain majority coalitions for a far-reaching contraction of social policy (Stephens, Huber, and Ray 1999). The reasons have already been outlined. The broad scale of public support. the intensity of preferences among programme recipients, the extent to which a variety of actors (including employers) have adapted to the existing contours of the social market economy, and the institutional arrangements which favour defenders of the status quo make a frontal assault on the welfare state politically suicidal in most countries.

Yet the chapters in Part I of this volume also suggest that pressures associated with post-industrialism, intensified in some respects by globalization. have rendered the maintenance of the status quo an increasingly unrealistic 


\section{Coping with Permanent Austerity}

option. Continuing low growth coupled with the challenges of creating service sector employment, population ageing, and the overcommitments of existing policies are already generating intense pressures. Tax levels strain public tolerance. Payroll tax burdens and their possible adverse impact on employment and wages create tensions within the traditional support coalitions of the welfare state (Visser and Hemerijck 1997). Barring an extremely unlikely return to an era of high economic growth, fiscal pressures on welfare states are certain to intensify. While tax increases may contribute to closing the gap between commitments and resources, it is difficult to imagine that in many European countries changes in revenues alone could be sufficient to maintain fiscal equilibrium. Thus, even strong supporters of the welfare state increasingly acknowledge that sustaining basic arrangements will require significant reforms. It is a context of permanent austerity.

The prospect of permanent austerity transforms political conflicts over the restructuring of social policy. Welfare state conflict is often portrayed as a clash between those wedded to the status quo and those eager to dismantle basic social protections. In countries where aggressive advocates of neoliberalism have been in power, such as New Zealand and until recently the United Kingdom, this has not been too inaccurate a portrayal. Yet in a climate where social trends make pressures on budgets intense and unrelenting, political cleavages are likely to become more complex. Those advocating restructuring will include many who wish to preserve and modernize key elements of the social contract, but seek to do so in a manner which does not create unsustainable budgetary burdens, contributes to economic performance, and gives emerging social demands some chance of competing for public attention and resources with well-established ones. In the current climate, restructuring must be distinguished from retrenchment or dismantling.

My central contention so far is that neither the alternatives of standing pal or dismantling are likely to prove viable in most countries. Instead, as in many aspects of politics, we should expect strong pressures to move towards more centrist-and therefore more incrementalist-responses. Those seeking to generate significant cost reductions while modernizing particular aspects if social provision will generally hold the balance of political power. In Claus Ctfe's words, the objective for those wielding electoral power in most countries will be 'smooth consolidation' (Offe 1991).

A useful initial framework for fleshing out this claim is a simple version of the pivotal politics argument suggested in recent studies of American poliucs (Krehbiel 1998; Brady and Volden 1998). In any collective choice iltuation where policy preferences can be arrayed on a single continuum, thare is a pivotal actor whose vote determines whether an initiative moves forvard or is blocked. This pivotal voter is likely to wield disproportionate power, and policy outcomes should generally gravitate towards that location. Pivotal voters need not be median voters. A great deal turns on the 
institutional environment governing choice. Depending on the significance of multiple vetoes and super-majoritarian systems, the pivotal voter will generally be closer to the status quo than the median voter-often much closer. In the United States, for instance, if a President is prepared to veto legislation, the pivotal voter in the legislature is not the one generating a bare majority, but the one producing the two-thirds majority required for a veto override. ${ }^{4}$

In practice, the political vulnerability of those seeking to modify popular social welfare programmes is such that they will often seek relatively broad consensus on reform rather than a 'minimum winning coalition'. Broader consensus legitimates the claim that policy change is necessary and intended to sustain rather than gut the programme under review; it thus provides essential political cover (Weaver 1986). The desire to make reform durable generally points in the same direction. Especially with large, complex, and deeply institutionalized programmes like health care and pensions, social actors place a high value on predictability and continuity in policy. Reform is not enough; powerful interests seek reasonable assurance that the new policies can be sustained. This again encourages the assembly of grand coalitions. Such coalitions, often informal and issue-specific, extend the range of actors with a stake in the reform outcome, and increase confidence that the next election will not overturn the new initiatives.

In other words, the pivotal actor in practice will generally be closer to the status quo than the actor identified by a formal analysis of the institutional preconditions for minimum winning coalitions. In a wide range of countries, the coalitions engaged in the restructuring of welfare states have been far broader than minimum size, incorporating key interest organizations as well as political parties outside the current government. Such a broadening purchases the increased legitimacy and potential durability of enacted reforms. Most often, the price is a more incremental adjustment than would have been (theoretically) possible with a smaller coalition.

A final, related factor in pushing the 'pivot' towards the status quo is the possibility that the governments capable of enacting reform at a limited poliiical cost will be those possessing the greatest credibility with voters on the issue (F. Ross 1998). Following a 'Nixon goes to China' logic, it will often be those governments with reputations of support for the welfare state that have the greatest room to manoeuvre. Yet the very factors that produce such credibility (past commitments, ideological orientations, and the nature of a party's core constituencies) make it unlikely that the favoured party will use its enhanced manoeuverability to dismantle established social policies. Again political incentives point towards more moderate, modernizing reforms.

\footnotetext{
4 More precisely, it is the voter producing a two-thirds majority in the chamber where tha! voter's preferences are closest to the status quo.
} 


\begin{tabular}{lllll}
\hline Q & C & V & M & $R$
\end{tabular}

FIG. 13.2. Identifying the viable space for policy reform.

Of course, students of comparative public policy have long recognized the role of positive-sum bargaining among crucial organized interests and political parties. In most advanced industrial democracies the new economic and fiscal environment has transformed, but not undermined the conditions for consensus-oriented policy making based on political exchange. What has changed is the 'currency' for such exchanges. Traditionally, labour's contribution to consensus was wage restraint. As Rhodes argues, even following the demise of Keynesianism this contribution remains important. Yet reformers of the welfare state also require credibility and legitimacy, particularly in the eyes of voters. Left and centre-left parties, and/or trade unions, generally need to be brought into reform coalitions to make the restructuring of welfare states politically sustainable.

The implications of the discussion so far can be seen in Figure 13.2. Depicting policy reforms on a continuum from the status quo (q) to a fullfledged neoliberal agenda of radical retrenchment (r), one would expect the median voter $(\mathrm{m})$ to be a considerable distance from ( $\mathrm{r}$ ). The need to surmount institutional veto points pushes the government reform agenda back to (v), and the desire to gain legitimacy-enhancing and stability-inducing consensus promotes a further move to $(c)$. My argument is thus that in most of the affluent democracies the viable reform space will be, at a maximum, in the region (c)-(v). Reform thus entails a substantial shift from (q), but it is a long way from (r).

\section{TWO MAJOR COMPLICATIONS}

This is of course an extremely stylized treatment of reform politics. A more sarisfying account would need to complicate the analysis in two crucial $r$ :spects. First, one needs to develop a more nuanced conceptualization of the reform agenda, or, in social science terms, the dependent variable. Second, one needs to consider the distinctive reform dynamics of different welfare stare regimes. Each of these complications represents an important part of the surrent agenda for research on the politics of the welfare state.

\section{Three Dimensions of Welfare State Restructuring}

One of the striking features of current comparative research on the welfare sta $e$ is the lack of consensus on outcomes. How much, and in what ways, have 
welfare states changed since the end of the post-war boom? The authors in this volume generally depict most reforms in most countries as incremental rather than radical, and focused on restructuring rather than straightforward dismantling. However, some have argued that the degree of cutbacks has been more severe (Clayton and Pontusson 1998). Even among those who see the overall degree of change as fairly limited, there may be little agreement about how to characterize the nature and scope of change cross-nationally.

It is difficult to exaggerate the obstacle this dissensus creates for comparative research. As Kitschelt notes in his chapter, it is impossible to seriously evaluate competing explanations when there is no agreement about the pattern of outcomes to be explained. Thus, it is important to ask why researchers have so much trouble with the dependent variable.

The problem lies partly in the concept of the welfare state itself, partly in data limitations, and partly in limitations of current theorizing about welfare state change. 'The welfare state' is generally taken to cover those aspects of government policy designed to protect against particular risks shared by broad segments of society. Standard features, not necessarily present in all countries, would include: protection against loss of earnings due to unemployment, sickness, disability, or old age; guaranteed access to health care; support for households with many children or an absent parent, and a variety of social services-child care, elder care, etc.-meant to assist households in balancing multiple activities which may overtax their own resources.

Needless to say, this list covers an extremely wide range of government activity. Furthermore, the trend in scholarship has been to broaden the already extensive domain of the subject matter. Recent analyses have advocated more attention to public/private interplay (e.g. Shalev 1996; Howard 1997) and to the interfaces between the public sector, the market, and the household (Orloff 1993; Esping-Andersen 1999; O'Connor, Orloff, and Shaver 1999). In this volume, Schwartz makes a similar appeal for extending attention to systems of social protection built into the regulatory arrangements governing particular economic sectors. There is little doubt that this broadening has had salutary effects, forcing attention to dimensions of social life that had previously received scant attention, and illuminating the extent to which welfare states are nested in a set of broader institutional arrangements.

Yet as the concept of the welfare state, or welfare regime, 'stretches', it becomes inevitable that quite distinct processes and outcomes will be joined together under the umbrella of a single master variable (Collier and Levitsky 1997). This in turn spreads confusion in two ways. First, it fuels a process where analysts discussing what has happened to 'the welfare state' find themselves talking past each other because each is concerned with distinct dimensions. Second, it makes efforts to develop summary measures of what has happened extraordinarily difficult. The complexity of this multifaceted 


\section{Coping with Permanent Austerity}

concept cuts against our attempts to generate the relatively parsimonious measures of outcomes that make a serious enterprise of comparative explanation possible.

A second problem stems from data limitations. Even if we agree about the outcomes that we are interested in measuring, how do we carry out the measurements? This problem has become more acute as-again for quite good reasons-analysts have criticized simple efforts to characterize outcomes through indicators of public or social expenditure. Following EspingAndersen's lead, there has been a broad recognition that many of the theoretically relevant outcomes of welfare state change will simply not be captured by expenditure data. Indeed, I have argued elsewhere (Pierson 1994) that this is especially true in the current environment. There is every reason to believe that policy makers will seek systematically to engineer changes that produce their major expenditure implications only at a later point in time. In short, there is probably no substitute for investigations that pay attention to fairly detailed dimensions of policy change, including attempts to map their (perhaps uncertain) long-term implications. Rigorously applying consistent criteria to even a small subset of the affluent democracies is a timeconsuming and expertise-taxing enterprise. ${ }^{5}$ Carrying out such research for the affluent democracies as a whole would require the efforts of a large and well-funded team. So far no one has carried it out. ${ }^{6}$

The final element of the 'dependent variable' problem stems from limitations of theory. It is this issue that I want to explore in more detail here. One of the hidden premisses of much recent writing on the welfare state has been a return to the simple dichotomy of 'more' vs. 'less'. Implicitly, change is measured along a single continuum, stretching from the intact (or even expanding) welfare state on one end to the seriously eroded or dismantled on the other. Yet here again Esping-Andersen's core insights retain force. In a context where actors have complex motives, and the dependent variable is so heterogeneous, attempts to reduce change to a single dimension will be counterproductive.

Instead, starting from the perspectives of prominent actors in the reform process, we can think about change along three dimensions: re-commodification, cost containment, and recalibration. ${ }^{7}$ Each constitutes a potentially important dimension of welfare state restructuring. Any effort to focus on only one will necessarily distort what the process of restructuring

\footnotetext{
Two excellent examples are Alber $1998 b$ and Lindbom 1999. Alber covers three countries, although he limits himself largely to transfer programmes. Lindbom covers one country.

" The voluminous Scharpf/Schmidt project probably comes closest, but it does not attempt to systematically measure policy outcomes at the level of programmes across the countries in their study.

I am grateful to Jonathan Zeitlin for suggesting the term 'recalibration'.
} 
is about. For any welfare state, or any particular welfare state programme, we can fruitfully think about the extent to which reform agendas and policy outcomes involve change along each of these dimensions.

\section{Re-commodification}

De-commodification, in Esping-Andersen's influential formulation, 'occurs when a service is rendered as a matter of right, and when a person can maintain a livelihood without reliance on the market' (1990: 21-2). For Esping-Andersen, the centrality of de-commodification stems from his earlier reflections on the construction of the social democratic welfare regime (Esping-Andersen 1985). He argued that this regime was fashioned through the efforts of a highly mobilized and well-organized working class, which sought to use political power to overcome its vulnerabilities in the labour market. Re-commodification essentially involves the effort to reverse that process-to restrict the alternatives to participation in the labour market, either by tightening eligibility or cutting benefits.

Particularly for those who see the current era as defined by the rise of business power, re-commodification stands as the key dimension for an investigation of welfare state restructuring. The transformation of social provision, from this perspective, is primarily about dismantling those aspects of the welfare state that shelter workers from market pressures, forcing them to accept jobs on employers' terms. This formulation has proven particularly central to analyses of welfare state reform produced by those who come to the topic from previous work on industrial relations. For these scholars, the shifting balance of power between employers and unions stands at the centre of political analysis (Clayton and Pontusson 1998; Swenson 1991b).

Re-commodification clearly represents an important dimension of welfare state change. Yet it is increasingly evident that the basic logic of decommodification outlined in Esping-Andersen's Three Worlds was at least somewhat misleading even for the period of welfare state expansion during the post-war period. ${ }^{8}$ It suggests an image of welfare states foisted on capitalists. The problem with this line of thinking is not that it takes capitalism too seriously, but that it fails to take capitalism seriously enough. These are, after all, economies where investment depends on the capacity of capitalists to earn profits, and where the need to induce investment therefore confers substantial political power (Lindblom 1977). The question thus arises: How would programmes seriously damaging to economic performance thrive so extensively for so long?

B As Ann Orloff has stressed to me, commodification's connotation of diminished autonomy or choice is also problematic when applied to women, for whom the shift from unpaid household work to participation in the paid labour market may enhance rather than diminish autonomy. 
As Manow stresses in his chapter (see also the contributions of Rhodes, Swank, and Huber and Stephens) the attitude of private firms to the expansion of the welfare state cannot be reduced to one of recalcitrant opposition to de-commodification. To argue that employers have been enthusiastic builders of the welfare state would be revisionism run amok. Yet particular elements have been enormously appealing to particular employer interests, facilitating rather than impeding their core strategies (Mares 1998). Moreover, in many other respects employers have adjusted to welfare state arrangements--and policy makers have accommodated the welfare state to employers - over extended periods of time. As Soskice (1999) has argued, particular types of firms are likely to thrive in particular institutional settings. Thus, there is often a strong co-evolutionary aspect to the intersection between varieties of capitalism and systems of social provision.

This is not to suggest that commodification has not been a relevant dimension in recent struggles over the welfare state. For particular actors, in particular countries, with respect to particular programmes, this dimension has been highly salient. 'Work incentives' have been the focus of concern in many cases, ranging from the reform of Dutch disability pensions to the abolition of AFDC in the United States. Yet there remains considerable variation in the extent to which welfare state reform has focused on improving work incentives. All of the studies in Part IV emphasized that reform is often not primarily about re-commodification. As Wood argues, even actors who one might think would make this a high priority-e.g. German employers-have often had more pressing concerns. The task for analysts then becomes threefold: to identify the conditions under which a focus on re-commodification is significant, to establish the degree of change along that dimension, and to explain the observed patterns. At the same time, one must avoid the temptation to reduce the discussion of welfare state restructuring to this single aspect.

\section{Cost Containment}

In his powerful critique of expenditure-based analysis of welfare state variations, Esping-Andersen observed that spending levels were essentially derivative of, and often not a good proxy for, other outcomes (such as decommodification, poverty relief, or status maintenance) which actors valued. During the period of welfare state expansion, he argued pointedly, 'it is difficult to imagine that anyone struggled for spending per se' (Esping-Andersen 1990: 21).

In the current climate, however, people do fight against spending per se. ndeed, this is a defining characteristic of the era of austerity. As I argued i) Chapter 3, a range of pressures, including the shift from manufacturing 
to services, demographic and household change, and the maturation of governmental commitments are placing inexorable demands on government budgets. Deficit reduction is a high priority for many of the countries that have joined or seek to join the European Monetary Union. In many contexts, powerful actors are concerned first and foremost with the implications of reform for levels of government expenditure. Of course, the imposition of austerity may become a vehicle for the pursuit of other ambitions, but often the principal focus is cost containment itself.

With the exception of Wilensky's important work (Wilensky 1981), social scientists have generally treated social expenditure and taxation as two distinct realms of research. In reality, of course, they are two sides of the same coin, inextricably linked. The need to finance public spending in the current environment often becomes the most powerful constraint on existing social policy arrangements. Employers and financial interests worry about high tax levels because of their potential impact on profits-an impact that may be felt through a number of distinct channels. In many countries, for instance, a major preoccupation is the fear that high fixed labour costs, generated in part by payroll tax rates, are seriously impeding the ability of employers to hire low-skilled workers.

Of course, the other political channel for opposition to taxes runs through the electorate. As the welfare state has expanded, its financial underpinnings have shifted, necessarily, to heavy reliance on funds from middle-income households. Higher taxes, combined with slower growth of real incomes, have generated popular discontent. In most countries, politicians must also cope with the downside of pay-as-you-go financing. As Myles and Pierson argue, the current era marks the reversal of the favourable political dynamic that accompanied the phase-in of pay-as-you-go pension systems. During the 'golden age' politicians could make generous promises while deferring the cost (i.e. high payroll tax rates). Today's politicians, rather than being in a position to claim credit for new initiatives, act primarily as the billcollectors for yesterday's promises. Although voters almost everywhere retain widespread allegiance to public social provision, these sentiments are now intermingled with stiff resistance to significant tax increases (Bonoli, George, and Taylor-Gooby, forthcoming).

Governments face the unenviable task of reconciling strong tendencies for higher outlays with the potential for voter backlashes and the possibility that new taxes will damage economic performance. At the same time, most countries face tighter constraints on their ability to run deficits (most obviously in countries subject to the convergence criteria of EMU). In this climate, cost containment itself emerges as a top priority. Again, the questions for analysts are to identify the circumstances where a focus on cost containment becomes prominent, to establish the degree to which that goal is achieved, and to explain the patterns identified. 


\section{Recalibration}

Still, the agenda confronting contemporary welfare states cannot be reduced to cost containment plus commodification. By recalibration I mean reforms which seek to make contemporary welfare states more consistent with contemporary goals and demands for social provision. Two different types of recalibration should be distinguished. Rationalization involves the modification of programmes in line with new ideas about how to achieve established goals. Updating concerns efforts to adapt to changing societal demands and norms-e.g. changes in the household, the life course, the nature of the labour market, or the age composition of societies. Rationalization includes attempts to correct obviously 'incentive-incompatible programmes' or cases of overshoot which may become evident over time, especially if external circumstances change in a way which greatly changes the functioning of programmes. Examples might include disability programmes in the Netherlands, or public service pensions in France and Italy. This kind of modernization would also include reforms of service systems, including health care, designed to improve the efficiency of provision or the responsiveness of such systems to consumer needs and demands.

The reform of Sickness Pay in Sweden can serve as an example of rationalization. By the mid-1980s, absenteeism rates in Swedish workplaces began to reach extremely high levels. There was fairly broad agreement that sick pay programmes were being abused-that these programmes were helping to producé high rates of absence from work rather than, as intended, providing protection against an important social risk. Spending rose sharply, from under 2 per cent of GDP in the early 1980s to almost 3 per cent of GDP in 1988 (Benner, Vad, and Schludi 1999: graph 23). The result was a consensus-partial and not without conflict-on a set of reforms to correct these tendencies. Replacement rates were cut, and waiting days added. Revenue-neutral changes were introduced to increase the incentives of employers to monitor use of sick pay provisions. Both the pattern of reforms and their timing suggest that the dominant concern was to restore sick pay to its originally intended role rather than to worsen the terms on which genuinely sick workers could choose to be absent from work.

This is tricky territory analytically. Since in the current context these reforms will often be designed to save money, how do we distinguish the impact of new ideas about how to do things, or efforts to recalibrate errant programmes, from simple cutbacks in provision? Yet clearly we do not want to smuggle all modifications of programmes into a framework of 'assaults on the welfare state'. Over time actors will sometimes discover that particular programmes do not work as intended, or they will determine that there may be better ways of achieving their goals. In such a context, they will push for changes. Thus, recent reforms in Swedish health care provision have 
produced considerable reorganization and resulted in public employment reductions, particularly among the low-skilled. From one vantage point (Clayton and Pontusson 1998) this represents a fundamental assault on public sector workers. From another, however, it represents an attempt to increase productivity in the public sector in order to provide high-quality and flexible services to consumers at a politically sustainable cost. The equation of public sector reform with simple retrenchment or the roll-back of the state is highly questionable without evidence that cost-savings have reduced service quality.

Updating involves the modification of existing programmes, or the initiation of new ones, in response to newly recognized social needs. A defining characteristic of the current era is the coexistence of social conditions which are in many ways 'new' with welfare states which are in many respects decidedly 'old' (Esping-Andersen 1999). As has been discussed, mature welfare states will tend to be characterized by various forms of stickiness. In addition, many current policy outcomes are the lagged effects of decisions taken decades ago. There is thus often a considerable 'mismatch' between emerging social risks and shared understandings of appropriate targets for state intervention, on the one hand, and the existing array of government social policies, on the other. The various aspects of this mismatch constitute an important dimension of restructuring agendas in contemporary welfare states.

Problematic as the concept of recalibration might be, it is more problematic to reduce the nature of current welfare state restructuring to simple cost containment plus re-commodification. A variety of initiatives, dealing with issues such as gender equity and social exclusion, simply cannot be squeezed into these other categories. Consider some of the most striking initiatives of recent years: the introduction of 'private' but essentially mandatory superannuation in Australia (C. Pierson 1998); the establishment of long-term care insurance in Germany (Götting, Haug, and Hinrichs 1994); the enactment or expansion in many countries of a range of subsidies or 'contribution credits' for unpaid caring work (Daly 1997); and the marked expansion of various initiatives to 'make work pay' by subsidizing the terms on which workers enter the low-paid labour market (Myles and Pierson 1997). None of these initiatives can be incorporated into a simple vision of expanding markets (commodification) and contracting states (cost containment).

Introducing these three dimensions of welfare state restructuring confers several very considerable analytical advantages. First, breaking down the very broad category of 'change' into discrete dimensions sharpens our capacity to discern distinct patterns in outcomes. One can identify striking variations both across policy arenas and across countries. Particular sectors of the welfare state tend to be much more preoccupied with one or another dimension of welfare state restructuring. The differences are clearly highlighted in 
this volume's 'policy domain' chapters (Part IV). Wood shows that in the case of labour market reform the primary agendas are re-commodification and recalibration, in differing and quite interesting configurations. By contrast, cost containment is a much less significant motivation for policy reform. In the case of health care and pensions, on the other hand, cost containment is the issue in most countries, though flanked in some cases by efforts at modernization. Only rarely will re-commodification provide the primary lens for analysing the character of reform in these core welfare state sectors. To take a third example, in the case of family policies, the main pressure all welfare states face is the need to adapt social policy arrangements to the radically transformed interfaces between market, state, and households.

Distinct dimensions of welfare state restructuring will be of varied salience not only across programme areas, but across countries and over time. For instance, acute fiscal crises or the dash to meet EMU's convergence criteria obviously place a premium on cost-containment efforts. More generally, I will argue in the next section that the three different 'worlds' of contemporary welfare capitalism give rise to distinct policy agendas and, in part as a result, distinct competing political coalitions and reform dynamics. It has been in the liberal welfare states that a focus on re-commodification has been most pronounced. These already highly commodified welfare states have become more so-especially in Britain, New Zealand, and the United States. By contrast, recalibration and cost containment have been more central to the policy agenda in Continental welfare states, while cost containment has been the principal issue in the social democratic welfare states of Scandinavia. A focus on multiple reform dimensions thus allows the analyst to highlight the distinct problem loads of different welfare states.

Finally, disaggregating these reform dimensions increases our capacity to make sense of relevant political processes, facilitating more nuanced accounts of actor interests and political activity. Different actors may be concerned about distinct dimensions of reform; particular actors may have multiple but partly conflicting objectives. Furthermore, because of these multiple priorities there may be unsuspected opportunities for issue-linkage and negotiated change in which different actors trade off lesser concerns for greater ones. As noted in the chapters by Bonoli, Rhodes, and Myles and Pierson, one of the striking observed outcomes in some configurations is unexpected coalitions based on quid pro quos. One can place this in the framework outlined in the first part of this chapter. Recognizing the multidimensionality of reform is crucial in a context where many actors agree on the need for 'change' but have different interests and priorities. Analysts elsewhere (Levy 1999; Myles and Pierson 1997) have stressed the centrality of compromise and the search for positive-sum trade-offs under conditions where broad political coalitions are necessary and straightforward retrenchment is politically difficult to sell. 


\section{Three Distinct Welfare State Regimes}

The second necessary complication of my initial framework stems from the need to recognize the existence of very distinct political and policy configurations-distinct regimes-within the ranks of the affluent demo-cracies. Up until now I have spoken of essentially a single 'logic' of welfare state reform. Just as we have to distinguish different reform dimensions, however, we also need to recognize the existence of quite different settings for the emerging politics of restructuring. ${ }^{9}$

Esping-Andersen's typology of three worlds of welfare capitalism-liberal, conservative, and social democratic-has been enormously influential. At the same time, it has been subjected to frequent criticisms, mostly stressing that particular countries are poorly categorized, or arguing that other dimensions of variation are neglected. Any typology covering the complex realities of a large number of countries is vulnerable to this kind of challenge. Yet there are excellent theoretical and methodological reasons to organize the explanation of variance in outcomes around an analysis of distinct regimes rather than lumping all OECD countries into a single pool in which one scrutinizes variance along a single, continuous range of 'independent' variables.

'To talk of a regime', Esping-Andersen maintains, 'is to denote the fact that in the relation between state and economy a complex of legal and organizational features are systematically interwoven' (1990: 2). What was most compelling in Esping-Andersen's analysis of modern welfare states was his insistence that welfare states be seen as part of complex historical configurations. ${ }^{10}$ The 'three worlds' did not result from 'more' or 'less' of a few discrete, independent master variables, but from the interactive and cumulative effects of a number of interdependent causal factors. 'Variables' may have a particular impact only when accompanied by a set of additional factors. This perspective has strong affinities with Ragin's concept of 'complex conjunctural causation' (Ragin 1987). As Shalev has put it, the argument is that welfare regimes should be seen as 'a limited number of

${ }^{9}$ In case it is not obvious, I should acknowledge that many of the arguments in Pierson 1994 and Pierson 1996, especially those which de-emphasize the contemporary role of organized labour, suffer from precisely this defect. This criticism is effectively advanced in Visser and Hemerijck 1997.

10 In this respect, the analysis runs directly parallel to a very prominent theme in comparative political economy, emphasizing the varieties of contemporary capitalism (Kitschelt et al. 1999b; Hall 1999; Soskice 1999). In Soskice's influential account, 'there are strong interlocking complementarities between different parts of the institutional framework. Each system depends on the other systems to function effectively' (1999: 109). Spurred in part by Esping-Andersen's work, a number of researchers have begun to explore the connections between production systems and welfare state regimes (see Ebbinghaus and Manow 1998; Huber and Stephens, Manow, Rhodes, and Wood, in this volume). 
qualitatively different configurations with distinctive historical roots'. Causally, the claim is that "countries cluster on policy because they cluster on politics' (Shalev 1999: 13, emphasis in original). In this framework, it makes no sense to argue for a linear relationship between independent variables and dependent variables, e.g. that 'any discrete increment of Catholicism or absolutism ought to yield a discrete and uniform increment in pension "corporativism" "(ibid.). ${ }^{11}$

The arguments about path dependence discussed earlier in this chapter and elsewhere in this volume (Myles and Pierson, Wood), as well as the contributions which focus on linkages among regime features (Manow, Huber and Stephens) point in the same direction. Path-dependent processes are very likely to be prevalent in contexts where a set of organizations and institutions develop together over extended periods of time, reinforcing each other through processes of mutual adaptation and competitive selection. Institutions and organizational actors that constitute a poor fit are less likely to survive over time. Such processes foster the emergence of quite distinct configurations, containing many elements which 'make sense' in the context of the others. To take a prominent example (Huber and Stephens 1999) a number of factors operated together to create the 'Social Democratic service state'. In particular, the rapid entry of women into the workforce, in a context marked by social democratic party and union strength, fuelled demand for supportive social services. Efforts to meet that demand through public sector expansion both created additional opportunities for women's employment and strengthened political forces pushing for further expansions.

Different welfare state configurations are the products of complex conjunctural causation, with multiple factors working together over extended periods of time to generate dramatically different outcomes. There is no theoretical justification for arguing that a 10 per cent shift in the value on one variable or another will have a simple, direct, linear effect on outcomes across all cases. To clarify, let me discuss one example: the impact of political institutions on the prospects for reform in the current period. Most discussion of this issue has addressed welfare states in general. Pierson and Weaver (1993) stressed that there was no clear theoretical basis for believing that increased institutional fragmentation necessarily made retrenchment more difficult. The concentration of authority also concentrated accountability,

${ }^{11}$ Esping-Andersen himself employed such regressions, but as Shalev argues persuasively, there is an 'obvious mismatch between Esping-Ändersen's claims and his methods. ... The regression approach . . . treats both policy and politics as continuous variables. . . . It is hard to exaggerate the fundamental incompatibility between [multiple regression] and EspingAndersen's regime approach. ... In his hands [multiple regression] was simply a blunt instrument for tapping gross differences between groups of countries that could have been conveyed by the use of tables and charts without the implication of constant linear effects across countries' (Shalev 1999: 13). 
which might lead to difficulties in pursuing unpopular policies. This accountability/blame avoidance dynamic is important for understanding why even unified governments will often be cautious, for explaining the strategies that such governments employ, and for highlighting the possibility that aggressive action may lead to electoral backlash.

By now, however, the evidence would seem to show pretty clearly that on balance the concentration of political authority is an asset for those seeking reform. ${ }^{12}$ As Huber and Stephens argue, the experiences of the two pure Westminster cases, New Zealand and the United Kingdom, are particularly striking. New Zealand's National government was able to move aggressively on multiple fronts. The British Conservatives gradually learned to shift from a strategy of frontal assaults to one of relentless, low-profile adjustments, which whittled away important elements of the welfare state over time. By contrast, veto points in other countries have generated significant, sometimes overwhelming, obstacles to radical change.

Yet it is no accident that both these examples of major retrenchment in the absence of formal institutional veto points concern liberal welfare states, where social actors are disorganized and popular support for the welfare state is (while still extensive) more limited than elsewhere. It seems highly unlikely that the same 'value' on this particular independent variable would have similar consequences in a configuration where popular support for the welfare state was broader and/or the power resources of labour were greater - a conclusion which Bonoli's discussion of the French reform experience supports. The 'freedom' to produce radical reform stems not just from a high concentration of political authority, but from that factor combined with a number of other features of a particular configuration.

In analysing the dynamics of social policy restructuring, one needs to attend to both the particular scale and shape of welfare states and particular political contexts. With respect to the latter, the scope of popular support for social provision, the connections between social provision and systems of economic production, and the relationship between the electoral/ partisan arena and systems of interest intermediation are especially critical. In short, we need to recognize the existence of distinct worlds of welfare capitalism.

12 Again though, Swank's chapter suggests that while fragmented institutions might impede retrenchment efforts, they are also likely to slow welfare state expansion in the first place. This slowdown occurs both because of institutional fragmentation's direct role in blocking reform and because of its indirect negative effects on social solidarity through the promotion of interest heterogeneity. This is in keeping with a general presumption in much institutional research, namely, that the effects of institutions will generally be multiple and cross-cutting rather than simply direct and unidimensional. A different way to put this is that we need to distinguish between the short-term and long-term causal effects of institutional fragmentation. For a discussion of this point, see Shalev 1999. 


\section{Coping with Permanent Austerity}

Even if one accepts the basic case for treating cases holistically, as configurations rather than compilations of variables, one can nonetheless challenge Esping-Andersen's specification of regimes. A number of reasonable objections have appeared, and for particular purposes one might prefer a different typology. Yet I am struck by the extent to which other analysts, including those studying broader shifts in political economy, have gravitated towards similar demarcations (Iversen and Wren 1998; Kitschelt et al. 1999a; Scharpf 1997b). My view is that this reflects a reasonably tight fit between particular welfare state configurations and particular political configurations. This is indeed what one should expect if Esping-Andersen was correct in arguing that each regime type emerges from a particular political milieu.

As Walter Korpi has argued, in evaluating the heuristic merits of typologies, 'the analysis of causes and consequences of welfare states should be in the foreground' (Korpi 1999: 35). Ultimately, the crucial issue is whether the distinction among regimes provides leverage for explaining important variations across the relevant cases. In Section 3 of this essay, I argue that it does-although not always in the manner suggested by Esping-Andersen's own discussions. When combined with the disaggregation of reform dimensions outlined above, one can begin to make sense of variations both across regimes and among cases within each regime.

\section{RESTRUCTURING THE THREE WORLDS OF WELFARE}

What follows is a preliminary attempt to outline the distinct politics of welfare state reform in the three 'worlds', or regimes, of liberal, social democratic, and conservative welfare states. ${ }^{13} \mathrm{I}$ argue that the basic framework developed in Section 1 is helpful for making sense of what is happening in each of these three worlds. Each world, however, is composed not only of particular types of welfare states, but also of distinct political settings. Thus, the agendas for welfare state restructuring and the dominant political coalitions will vary. Furthermore, we can expect additional variation across cases within each world, and one of the major tasks for analysts should be to identify and explain that variation.

${ }_{13}$ A number of the cases sometimes considered in such comparisons are excluded from this analysis. Greece, Ireland, Portugal, and Spain are late developing welfare states, which were still very much in the process of welfare state construction at the end of the golden age. In my view this context raises quite different issues from those cases where affluence had been achieved and welfare states were already close to maturity by the mid-1970s. Switzerland and Japan represent distinct configurations that do not fit easily into any of the three regimes. 
By distinguishing among regimes, and disaggregating different dimensions of restructuring, one can identify patterns that would not be evident in a more unified analysis which tried to explain a single outcome (e.g. 'retrenchment') over the whole set of cases. In these respects, I follow Esping-Andersen's regime typology (although utilizing different outcome dimensions). On the other hand, our accounts of the political dynamics in the three regimes are quite different. ${ }^{14}$ The goal is to make the investigation complicated enough to capture and account for crucial elements of diversity, but not so complicated that it becomes impossible to identify general patterns.

\section{The Liberal Regime}

The liberal cases include Australia. Canada, Great Britain, New Zealand, and the United States. ${ }^{15}$ The most politically salient features of the welfare state constellations in these countries include the following (data on most of these features can be found in the Huber and Stephens chapter in this volume). Taxes, and spending, have remained low by international standards. Public sector service employment is also low. Many transfer programmes are income-tested, although the range of coverage varies from very narrow (the United States) to quite broad (Australia). In part as a consequence of the failure of the welfare state to meet demands for social provision, private sector activity in pensions and social services such as child care (as well as health care in the United States and New Zealand) is extensive. In many cases, tax expenditures subsidize private provision for the upper middle class (e.g. Howard 1997). Finally, these welfare state arrangements operate in the context of liberal market economies. There is no overlap between the world of liberal welfare states and the world of 'organized market economies'. Thus, there are numerous linkages, explored below, between liberal welfare state arrangements and the liberal or 'disorganized' model of capitalism.

${ }^{14}$ This is not an issue that Esping-Andersen has pursued in detail. In Three Worlds he identified distinct political cleavages in each regime. In Postindustrial Economies he seems to maintain, although without much elaboration, that 'path dependence' and 'median voters' will prevent major policy change. The current analysis points to quite different political cleavages in the three worlds and argues that while path dependence and pivotal voters channel reform, they are unlikely to prevent it.

is F. G. Castles and Mitchell (1993) have persuasively argued that the two Antipode countries should be seen as a distinct 'wage-earner' model, in which protectionism combined with intensive labour market regulation to produce relatively egalitarian outcomes without extensive formal welfare states. However, the wage-earner model, grounded in protectionism, came under acute pressures from a changing international economy. For these countries globalization has clearly mattered enormously. This alternative model began to break down in the mid-1970s, forcing a gradual shift towards broadly liberal arrangements. Australia, in particular, remains somewhat distinct from other liberal cases in the continuing role of politically mediated wage bargaining. The differences are less pronounced than they were two decades ago, however, especially following the recent period of Liberal-National governance. 


\section{Coping with Permanent Austerity}

The political constellations of these cases also share a number of common features. First, and most crucial is the weakness of encompassing interest organizations. By comparative standards these are cases where organized labour has modest political capacities. Again, there is considerable variation among these countries, ranging from Australia at one end to the United States at the other. It is not only that labour is weak in these cases; the capacities of employers for collective action are also limited. In Soskice's words, 'companies have little capacity to coordinate their activities collectively. Their inability to act collectively means that they cannot combine to negotiate discretionary framework solutions with the state' (1999: 110). In short, with the partial exception of Australia, not only does labour lack the power to veto change, but the capacity of these systems to pursue negotiated reform through systems of organized interest intermediation is very low. Unlike the case in other welfare state regimes, policy changes must be executed almost exclusively through electoral and partisan politics.

Several crucial features of the electoral/partisan environments thus deserve special emphasis. First, until New Zealand's recent reform, none of these cases employed proportional representation. Instead, 'first-past-the-post' electoral systems have been the norm. ${ }^{16}$ Thus, all of these countries have had strong tendencies towards two (or two-and-a-half) party systems. With the exception of the United States, where division between Congress and the President has become the norm, these systems tended to produce single-party governments. They varied, however, in the extent to which political institutions provided checks on these governments. New Zealand (pre-1996) and Great Britain constitute pure 'Westminster' models of 'elected dictatorship'. By contrast, the federal systems of Australia, Canada, and the United States create additional veto points, the severity and nature of which varies across countries, issue area, and electoral context.

Furthermore, there is little question that the scope of popular support for public social provision tends to be more conditional in these cases, although again with considerable variation (Svallfors 1997). One can see here how multiple features of a particular configuration point in the same direction. Because these welfare states are relatively small, the 'core' support group for social provision is also relatively small. Reliance on means-testing may divide those who benefit from many taxpayers. The political clout of labour unions, a traditional bastion of support, is also relatively modest. The institutionalization of (often state-subsidized) market alternatives weakens middle-class attachments to public provision. High levels of inequality are also associated, in many countries, with large class biases in electoral turnout. Low turnout among the economically vulnerable further diminishes their already limited political influence.

${ }^{16}$ Australia employs a 'preferential' voting system. Because voter's second choice matters, this will generally induce parties to moderate their policy stance. 
To be absolutely clear, the claim is not that a majority of voters tend to oppose the welfare state in these countries; nowhere is this true. Compared to the social democratic and Continental countries, however, pivotal voters are likely to possess weaker attachments to social provision, and to be more susceptible to alternative political appeals (such as the demand for tax cuts). Liberal welfare states thus provide the greatest potential for parties to reconcile political success and a relatively aggressive, even openly hostile stance vis-ä-vis significant components of the welfare state. Under particular conditions, pivotal voters may be within reach, and in some of these countries labour can be essentially excluded from playing a significant role. Thus, the political conflict between advocates of moderate restructuring and radical retrenchment is more equally matched than it is in the other two regimes.

This is reflected in the pattern of outcomes. By comparative standards, quite radical cutbacks have been achieved in New Zealand, and, to a lesser extent, in Great Britain (Stephens, Huber, and Ray 1999; Castles and Pierson 1996). Canada and Australia, on the other hand, have pursued a distinctive course, also marked by efforts at cost containment and commodification, but balanced by serious efforts to protect the most vulnerable. In the United States, change has been more limited, and contains elements of both tendencies.

Although the variations across countries both in policy outcomes and in inequality trends are quite striking, these outcomes are not sufficiently stable to allow firm conclusions about national trajectories. Australia's current National-Liberal government is seeking to erode many of the provisions that marked the accords reached between the Australian Labour governments and the trade unions between 1983 and 1995. Under the current British Labour government, important new policy initiatives emulate some of the Canadian and Australian strategies which combine a strengthening of work incentives with compensatory policies for those affected (Hills 1998). These recent developments suggest that partisan control of government may be most important in the liberal regime. This is indeed what we should expect given the relatively narrow base of welfare state support in these countries, and the dominance of the electoral/partisan arena for political action.

A defining characteristic of restructuring in all the liberal welfare states has been the priority placed on re-commodification. Indeed, both the emphasis placed on commodification and the degree of change has clearly been greater than in the other welfare state regimes. In all the liberal welfare states, programmes providing transfer payments to those of working age but out of the labour force-unemployment benefit and social assistance-have faced major cutbacks. Eligibility rules have been tightened, and benefit levels have been reduced significantly. Coverage rates (in Canada and the United States) and benefit levels (everywhere) for the unemployed have fallen sharply. Mosi dramatically, in Canada and the United States, national commitments to 
social assistance have been severely weakened. Provincial and state authorities have often moved aggressively to push the poor off social assistance rolls and into the workforce.

At first glance, this characteristic of liberal regime reform is puzzling. Why would these systems, already the most 'commodified' in the OECD, push so much more aggressively in this direction? Part of the answer lies in the political weakness of those who might resist commodification. Equally important, however, is the connection between income support and the labour market in political economies where wage flexibility is treated as the principal buffer against high unemployment. The deteriorating market position of low-skilled workers has confronted policy makers everywhere with difficult trade-offs (Iversen and Wren 1998; Scharpf 1997b). Consistent with the basic workings of a liberal, 'disorganized' market economy, all of these liberal countries have implicitly accepted that the new environment requires larger wage differentials, and, in particular, deteriorating relative wage conditions among the low-skilled. Yet this deterioration can only be carried out if exit options ('reservation wages') are not attractive. That is, the push for (downward) flexibility among the low-skilled implies a hardening of conditions for income support to those out of work. Improving 'work incentives' has thus been a common frame of reform, justifying stricter eligibility, benefit cuts, or even outright abolition of programmes.

Many comparative analysts view the liberal welfare states primarily as an analytical or normative foil for the 'real' welfare states of Continental Europe and Scandinavia. For these analysts, the policy changes just described are taken to define the essential outcomes for these cases. From this perspective, the United States is taken to typify the liberal world, and the welfare 'reform' which abolished Aid to Families with Dependent Children is taken as the paradigmatic policy change in the USA. Social policy dismantling and re-commodification are portrayed as the logical political destination for liberal welfare states in the new era.

The actual patterns, however, are both more complex and more interesting. All the liberal welfare states have shared in the shift towards recommodification, albeit at different paces and to different degrees. Yet there has been considerable variation in the extent to which this transition has been subsidized or buffered. The main political debate in the liberal welfare states has not focused on whether or not low-skilled workers should be in the labour market, but on the terms under which their participation should take place. The key issue is the extent to which commodification should be subsidized. Those advocating subsidization have accepted demands for reform in social assistance and unemployment benefit, but have sought to 'make work pay' by supplementing poverty-level wages available in an unregulated market with various forms of targeted social provision. Arguments in favour uf such provisions emphasize both social equity concerns and the need to 
foster the development of human capital. Many of these supplements are targeted on groups that are considered particularly vulnerable and/or particularly deserving of support, especially households with children.

The particular package of supplements varies, but may include some or all of the following: improved child allowances and access to affordable child care, reductions in social insurance contributions for the low-paid, an increased minimum wage, ${ }^{17}$ expanded access to public health insurance (in the United States), and the expansion or introduction of tax-based wage supplements. The last provision has been particularly important. All the liberal countries have introduced significant wage subsidies, operated through systems of taxation, for at least some of the working poor-usually families with children. Most dramatic has been the major expansion of the Earned Income Tax Credit in the United States and of the Working Families Tax Credit (formerly Family Credit), in Great Britain. In Australia, the universal child benefit was means-tested (although 60 per cent of the population remain eligible), but an expanded Additional Family Payment provided significant additional cash on a per child basis to working families.

Some of these subsidization initiatives could be dismissed as cosmetic embellishments to harsh exercises in retrenchment. Yet the overall scale of these mediating efforts is difficult to ignore. In the United States, for instance, while there were considerable cutbacks in AFDC and Unemployment Insurance even before the 1996 welfare reform, overall federal spending on low-income groups rose significantly in the late 1980s and the first half of the 1990s (Weaver 1998). By the time AFDC was transformed and largely handed over to the states, the federal government was spending twice as much per year on the rapidly-expanding EITC as it spent on AFDC (Myles and Pierson 1997). Along with modest increases in the minimum wage, EITC expansions since 1989 have contributed to a large real increase in earnings for single employed mothers with two children.

Cost containment has also been a major political priority in all these countries. Deficit reduction has been a dominant theme, and it has been common for centre and centre-left parties (e.g. Blair, Clinton, and the Australian Labour government) to commit themselves to policies of not raising taxes. This outcome is striking, given the relatively low levels of public expenditure in these countries, and the absence of anything like the Maastricht criteria to generate an external constraint. Although in the cases of the three economies dependent on export of primary goods (Australia, Canada, and New Zealand) one could point to external pressures for budget balance, it is difficult to make this argument for Great Britain or, especially, the United States. Within the liberal regimes, the more right-leaning position of the pivotal voter

${ }^{17}$ In the UK the Labour government has introduced a minimum wage for the first time. and set its level significantly closer to the median wage than is the case in the United States. 


\section{Coping with Permanent Austerity}

appears to facilitate a focus on expenditure (and tax) restraint, along with deficit reduction, even in the absence of an institutional forcing mechanism such as EMU.18

Cost containment efforts, however, have not on the whole generated the kind of radical roll-backs popularly associated with neoliberalism. Indeed, it is hard to discern a distinct liberal response in the big spending areas of health and pensions. Unlike the case of income maintenance for the ablebodied, there is no clear policy imperative. In both health care and pensions, outcomes appear to be heavily constrained by the particular policy arrangements established before cost-containment demands became paramount. Where there were well-established, deeply embedded policy frameworks in these areas, continuity has been more evident than change. Thus, in health care, Australia, Britain, and Canada have all made modifications of their pre-existing systems in an attempt to cut costs, but without challenging basic rights to quality care and in contexts where overall expenditures were increasing. In the United States, the major policy initiative was a failed attempt to dramatically expand health care coverage, albeit as part of a costcontainment strategy. New Zealand again stands out as a divergent case. Only there was a major effort undertaken to roll back the contours of state provision for health care.

As Giaimo's chapter demonstrates, there is no logic of liberal market economies that generates a strong push for market expansion and state contraction in the area of health care. On the contrary, a good case can be made for the opposite proposition: a strong state role in health care will generally serve the interests of most employers. The Clinton administration's reform initiative was based on this presumption. Its failure arguably reflected the incapacity of a 'disorganized' polity to facilitate the negotiation of acceptable terms (Judis 1995) and the path-dependent accumulation of vested private interests in the policy status quo (Hacker 1998) rather than a more fundamental conflict of interest between employers and consumers.

It is also clear that there has been no convergence in pension systems. Canada and the United States have modified their mature systems, emphasizing cost containment, with Canada introducing a significant element of funding. Not locked-in by past commitments, the UK and Australia have embarked on new (but very distinct) paths of funded provision. New Zealand has been unable to proceed in any direction. As Myles and Pierson show, path-dependent effects in pensions are very strong. At the same time, however, these path-dependent qualities largely reflect the 'congealed liberalism' of an earlier period. It is no accident that liberal countries were less likely

\footnotetext{
18 Again, the regime approach may help us to think about multiple paths to particular outcomes. Italy and the United States may both pursue vigorous deficit reduction, but this may reflect dramatically different political dynamics.
} 
to have mature, earnings-related PAYG systems by the end of the post-war boom. Thus, the substantial expansion of funding in Canada and Australia, and private (but heavily tax-subsidized) funding in the United Kingdom reflected not only the unmet demand for earnings-related provision, but also the availability of fiscal space and the relative sophistication of private financial markets made possible by an earlier history of liberalism. Within a regime analysis, it is the American Social Security system (like Britain's NHS in the case of health care) that emerges as anomalous. What is revealing is the so far modest transformation of this essentially Bismarckian element of the American welfare state.

As in the case of re-commodification efforts, the Canadian and Australian experiences of cost containment demonstrate their distinct path of restructuring. While programmes have been cut, significant efforts have been made to protect the most vulnerable. In each country, 'means-testing from the top' has been a dominant strategy for generating savings, and some of the savings have been redistributed to low-income groups (F. G. Castles 1996; Myles 1996). This quid pro quo has facilitated the maintenance of a reasonably broad, centrist consensus on restructuring efforts. In a particularly dramatic example, a 'clawback' of pension benefits for high-income seniors in Canada has been accompanied by a major expansion of minimum pension benefits. This shift has been so successful that it has allowed low-spending Canada to sharply reduce poverty rates for the elderly, which now approximate Scandinavian levels (Myles 1999).

One can see the differences within the evolving liberal world most starkly in measures of income inequality and poverty. Poverty rates have risen massively in the United Kingdom and New Zealand-far more than in any other OECD country. They have risen much more moderately in the United States-but from a higher baseline. On the other hand, at least through the early 1990 s there was little change in poverty rates in Canada and Australia. Although social welfare policy does not account for all of the differences across these cases, it has been quite important. Policy interventions that might have sheltered the poor from shouldering the costs of adjustment were actively dismantled in New Zealand and, until recently, Great Britain. In Australia and Canada (and much more tepidly in the United States) such protections were in many cases expanded to offset growing inequality in market incomes.

What explains this variation-straightforward and severe cost containment and re-commodification in New Zealand and the UK, compensated restructuring in Australia and Canada, with the United States as an intermediate case? New Zealand and the UK stand out as cases where there was little inclination or necessity for compromise in the pursuit of neoliberal goals. As has been discussed, the broad contours of the liberal regime type make such an agenda at least conceivable, while it is clearly beyond the reach of any likely political coalition elsewhere. In addition, however, two political 
conditions have appeared essential for such an aggressive coalition to achieve significant policy successes: first, a series of economic setbacks which discredited the policy status quo and its supporters; and second, a partisan-institutional configuration that translated an electoral plurality into a governing majority and allowed that majority to operate essentially unhindered (Huber and Stephens, in this volume; Schwartz and Rhodes 1999).

As Schwartz and Rhodes argue, the aggressive neoliberal agendas pursued in both Britain and New Zealand grew in part out of severe economic dislocations which underscored the need for major reforms. In both cases, the neoliberal projects were reactions to failed efforts to intensify policy strategies developed in the 1960s and early 1970s - Keynesianism, incomes policy, and expanded public spending in Britain, protectionism and state-subsidized production in New Zealand. The dramatic collapse of these projects lent credence to the neoliberal agenda, summarized in Thatcher's memorable phrase that 'there is no alternative'. At the same time, the loss of credibility and divisions generated by the failed projects demoralized and disorganized neoliberalism's political opponents.

A second, equally critical condition is a partisan-institutional setting that shifts the pivotal voter well to the right. I have argued that in general we can expect pivotal voters to be closer to the welfare state status quo than the median voter. Yet not only is that median voter likely to be comparatively far to the right in the liberal configuration, but the pivotal voter may actually be to the right of the median. As noted by Huber and Stephens, conservative parties in both Britain and New Zealand exploited Westminster, first-past-the-post electoral systems and a divided opposition to translate a plurality of votes into comfortable parliamentary majorities. During their eighteen consecutive years in office, for example, the British Conservatives never received more than 44 per cent of the vote. In New Zealand, parliamentary majorities in the four elections between 1984 and 1993 were based on electoral pluralities of $43,48,48$, and 35 per cent.

Even under such circumstances governments face constraints or run the risk of backlash at the polls. The Thatcher Government was less aggressive in attacking the welfare state than other aspects of the post-war order, and particularly cautious with respect to popular middle-class programmes like the National Health Service (Pierson 1994). New Zealand's National Party attempted to 'crash through or crash'. Ultimately it crashed, as a popular referendum in 1993 scrapped the Westminster model, which had permitted the government to ignore the median voter. Nonetheless, compared with more typical settings, this partisan-institutional configuration provided governments with greatly increased latitude to pursue unpopular policies.

Unlike New Zealand and Great Britain, neither Australia nor Canada had institutional arrangements that gave national governments unfettered control over the reform process. And unlike the United States, these 
governments did have well-organized, relatively encompassing interlocutors with whom to negotiate and implement a more consensual process of restructuring. In Australia, the crucial mechanism was a series of accords between the unions and the Australian Labour Party, based on a relatively high (by liberal standards) capacity for concertation and a shared appreciation for the political risks associated with failure (Schwartz 2000). We lack a convincing and detailed account of the political dynamics in Canada, but part of the explanation must be the manner in which a decentralized federal structure encouraged negotiation on the contours of adjustment between a series of national governments and powerful (and politically diverse) provincial premiers.

\section{The Social Democratic Regime}

The Scandinavian or 'social democratic' cases include Denmark, Norway, Sweden, and (more marginally) Finland. The basic characteristics of this welfare state configuration are well known: generous transfer programmes covering a wide range of risks with high replacement rates; public social services which, by comparative standards, are extremely extensive; a set of supportive family and labour market policies which generate very high rates of labour force participation for both men and women. The wide scope of public provision has, of course, also filled spaces which elsewhere were occupied by market arrangements. The private provision of social services, as well as pensions, remains extremely limited.

The political constellation in these countries includes multiple features that create very strong pro-welfare state coalitions. Union density is high, and the unions have maintained strong links with electorally powerful social democratic parties. Public sector unions are also enormous by comparative standards. Women are highly mobilized and committed to the social service state (which is both the primary source of women's employment and provides crucial support for women's labour force participation). Not surprisingly given these elements of the political setting, public opinion remains strongly supportive of the key features of the social democratic welfare state (Svallfors 1995, 1997; Goul Andersen 1997; Rothstein 1998a). The formal political systems of these countries contain few checks on parliamentary majorities, but the frequency of coalition governments makes political authority less concentrated than in the Westminster setting. At the same time, governments in these systems operate in a context of well-established and encompassing employer and union organizations, which represent both possible partners in dialogue and potentially formidable political opponents in cases where dialogue is absent or fails.

The basic results of welfare state restructuring in the social democratic cases reflect this context of very broad support for public social provision. 


\section{Coping with Permanent Austerity}

In the words of Eitrheim and Kuhnle, 'politicians who blow the trumpet of neo-liberal economics too loudly, and those who blow the tune that the welfare state is an evil invention, have a hard time surviving in Nordic politics' (Kuhnle and Eitrheim 1999). As Huber and Stephens persuasively argue (see also Stephens 1996), the immediate challenge confronting this regime has been the adjustment to a context of increased unemployment. The social democratic welfare states were in fiscal equilibrium with 3 per cent unemployment, but given their generous transfer programmes they ran into trouble when unemployment rose sharply. Once the increase was recognized as permanent, which occurred at different times in different countries, a combination of benefit cuts, economizing reforms in social services (especially health care), and tax increases were introduced to restore equilibrium. Crossnational variation in the timing and degree of restructuring largely reflects the timing and severity of economic crisis, and the degree of adjustment required. Thus, the most painful reform process occurred in Finland, and changes have been most modest in Norway. A strong argument can be made that this shift has largely been accomplished in all these cases while leaving a modestly less generous version of the pre-existing welfare state structures intact (Stephens 1996; Goul Andersen 1997). The primary task is to understand this general adjustment path for the social democratic regime, rather than cross-national variation inside it.

Before directly outlining the basic reform dynamics, it is necessary to address the orthodox interpretation of contemporary social democratic welfare state politics, which focuses on cleavages between the 'exposed' and 'sheltered' (or traded and non-traded) sectors. Esping-Andersen (1990, 1996a) identifies this as the predominant line of cleavage in social democratic countries. This view has been elaborated in several analyses by scholars working from a perspective shaped by the investigation of collective bargaining systems (Swenson 1991b; Clayton and Pontusson 1998; Iversen 1998a). In this volume, Schwartz offers a nuanced version of this sectoral argument, stressing the fact that both workers and employers in the traded sector may continue to support significant aspects of social provision.

Yet the evidence that this potential cleavage drives the politics of welfare state reform is, to be generous, extremely limited. Even in the social democratic countries where large-scale public sectors might be expected to generate such effects, strong advocates like Clayton and Pontusson are forced to acknowledge that the empirical support is modest. ${ }^{19}$ In his recent effort

19 And even this modest evidence has been subjected to sharp criticism (Lindbom 1999). In Sweden, the case considered by Clayton and Pontusson, there is little sign that social service employment has been targeted at the expense of transfer programmes. In some cases, it appears that services have actually been expanded. In others, notably health care, there have been drops in employment, but these appear to be linked to efficiency gains rather than declining quality of service. 
to determine if hypothesized cleavages over the welfare state are actually evident in public opinion Svallfors (1997: 292) concludes that 'public- versus private-sector employment does not seem to constitute a particularly important fault line. Differences are seldom statistically significant, and attitudinal differences pöint in different directions on different indices, sometimes showing public-sector employees to be more in favour of redistribution and small income differences than private-sector employees, sometimes the opposite. ${ }^{20}$ None of the 'issue area' chapters in this volume find evidence of such an alliance of 'tradeable' interests; nor do the chapters by Manow and Rhodes, which concentrate specifically on the contribution of economic actors to the formation of reform coalitions.

Why is there so little evidence for a claim that seems both credible and has received considerable scholarly support? The answers say a good deal about the current social democratic regime, and therefore help to provide a firmer basis for analysing its contemporary politics. First, the core assumption that 'productive' workers will rebel against 'unproductive' public sector ones is based on a doubtful interpretation of the role of public sector workers in the social democratic economies. Although often left implicit, explications of the tradeable/non-tradeable cleavage bear strong affinities to more extreme neoclassical treatments of the public sector which treat it as a domain dominated by 'rent-seeking'. From this perspective, a modestly paid public sector worker engaged in, say, the care of alcoholics or disabled children is essentially a parasite on the productive elements of society. Over time one would expect these productive elements to repudiate the extraction of rents and seek to roll back the public sector.

As Huber and Stephens (and, perhaps somewhat inconsistently, EspingAndersen 1999) argue, there is a strong case to be made for the beneficial economic effects of large-scale public service provision in the context of the broader social democratic regime. Many of these services focus on the development of human capital. Active labour market policy, training, and education provide crucial support for skill development, which in turn has made a key contribution to the high standards of living in the social democratic countries. At least as significant, however, is the success of this regime in supporting the efforts of many women to combine caring responsibilities, including child-rearing, with active participation in economic life beyond the household. Both the direct expansion of economic activity related to these policies, and the contribution that they make to fertility, represent considerable social assets.

${ }^{20}$ He adds a modest qualifier for the social democratic cases: 'some support is found for the hypothesis about the sector cleavage being most important in the social democratic regime. It is only in Norway and Sweden that sector appears to have any importance at all when explaining (re)distributive attitudes, but even here differences are not very substantial.' 


\section{Coping with Permanent Austerity}

All of this is missed by standard analyses of the cleavage between exposed and sheltered workers. For accounting purposes, economists often treat the outputs of public services as equivalent to the inputs, but we need to clearly distinguish our inability or lack of interest in measuring productivity/output from the lack of productivity/output. The evidence in public opinion continues to show that most voters in the social democratic countries perceive public social services as important contributors to their quality of life.

There is a second problem with the exposed/sheltered cleavage argument. Ironically for an analysis based around classes or class fragments, the focus on cross-class alliances is strangely abstracted from social context. ${ }^{21}$ Private sector workers, and their public sector counterparts, are treated as isolated monads. Yet we know that the labour markets in this regime are highly stratified by gender, with male workers overwhelmingly preponderant in the private sector and women concentrated in the public sector. In short, this hypothesized political cleavage is likely to run right down the middle of many households. If a private sector worker is married to a public sector worker, and they send their children to publicly financed child care, then what is the likely alliance pattern? Here is one clear advantage of bringing gender and household structure to bear on political economy approaches. It shows why some of the basic arguments about cross-class coalitions in welfare state restructuring may be far weaker than expected.

It is worth stressing that my arguments do not deny the relevance of the public/private divide with respect to wage bargaining processes. The division of the share of economic output going to labour has a zero-sum quality, and bargaining over this share is organized by unions structured along sectoral lines. Thus, the public/private cleavage is likely to be significant, and it is understandable that this cleavage occupies the attention of industrial relations scholars. What is in dispute is the extent to which this will carry over to the political determination of the 'social wage' in a context where the electoral realm constitutes an important domain of interest articulation. Here, evidence for the activation of a cross-classs, private-sector-based coalition remains meager. Tendencies for wage-bargaining cleavages to spill over into welfare state politics are partially if not totally offset by the strong reliance of almost all Swedish households on public sector services. These services either directly provide employment or indirectly provide the means to juggle demands of work and family.

If the political agenda is not one of undercutting public sector workers, what, then, have been the pressing restructuring issues in the social democratic countries? Overwhelmingly, they focus on cost containment and the recalibration of programmes within an essentially fixed budget. By contrast,

${ }^{21}$ In this respect as well, the focus on cross-class alliances reflects the strange marriage of post-Marxism and neoclassical economics. 
re-commodification has generally been a less important priority. This reflects the fact that while social democracy has traditionally been strongly 'de-commodifying', it has done so in a manner that produces very high rates of labour force participation and employment. 'Pushing (or pulling) people into the labour market' has always been part of the social democratic model. What have been distinctive are the quite favourable terms on which this occurred. Although what recent Swedish reformers have called the 'work-line' (everyone who can be working should be working) has been strengthened in all these countries, these changes have generally accentuated what had always been high expectations about work effort within the social democratic model. Much of the reform agenda has focused on rationalizing programmes which, either because of new labour market conditions or because of programme flaws, had gone astray from broadly accepted goals. As noted earlier, sickness pay in Sweden constitutes a clear example.

In most respects, however, the social democratic countries have had less need to focus on issues of recalibration-certainly when compared to the conservative regime which I will discuss in a moment. In particular, there has been relatively little need for what I have termed updating-the adjustment of old welfare states to new needs and demands. It should be emphasized that social democratic social policies already generate outcomes that the conservative Continental countries can only dream of achieving. The social democratic regime sustains very high rates of labour force participation for both men and women; it supports comparatively high fertility levels; it has extensive experience with active labour market policies designed to restrict exclusion and enhance skills; and it contains none of the clientelistic remnants that constitute such a costly problem on much of the European continent.

If the social democratic welfare states have succeeded in restoring their fiscal equilibrium over the medium term, their biggest long-term problem is reconciling the need for continuing cost containment with the maintenance of solidarity around the welfare state. As Rothstein (1998b) has forcefully argued, the political foundations of the social democratic welfare state have depended both on its compatibility with acceptable economic performance and on the ability to generate high-quality services for middle and upper middle income households. Sustaining the allegiance of these crucial voters, whose economic resources might provide an exit option, requires two difficult balancing acts. First, increasing heterogeneity in consumption tastes requires public sector services that provide meaningful choice, but without generating 'creaming' or 'tipping' effects which lead to class polarization in service consumption. Second, high-quality services must be sustained in a context where taxes are already high but 'Baumol effects' which accompany most social service provision generate continuing pressures for new spending. It is these dilemmas, rather than an effort to erode the position of public 
sector workers as part of a general liberalization, which have largely dictated public sector service reform in the social democratic countries.

\section{The Conservative Regime}

This third cluster of countries, variously termed conservative, Continental, Christian democratic, or Bismarckian, includes Austria, Belgium, France, Germany, Italy, and the Netherlands. The welfare state configurations of these countries generally include the following features: high levels of spending, strongly weighted towards transfers in general and pensions expenditure in particular; limited development of public sector employment; strong support for early labour market exit through early retirement schemes or unemployment and disability programmes (Ebbinghaus 1999); high levels of payroll tax financing; and explicit and implicit family policies (including tax structures, the absence of child care arrangements, and weak support for service sector job growth) which discourage women's labour force participation. These features are linked to a status-preserving 'Bismarckian' benefit structure, and, in many cases, to occupationally segregated (and often highly variable) pension and sickness funds. Unions and employers often play an important institutional role in the administration of these funds. In some cases (e.g. Italy), Conservative welfare states have also provided a strong basis for clientelistic welfare state politics (see Ferrera 1996).

The political constellations associated with these welfare state regimes are varied. Yet some generalizations are possible, and it should be stressed that in combination these generalizations suggest a political configuration quite different from those appearing in the other welfare regimes. Although not all these countries (e.g. France) could be defined as corporatist, systems of organized interest intermediation are generally important: 'across Europe, four out of five workers receive wages that reflect the outcome of a process of collective bargaining' (Golden, Wallerstein, and Lange 1999: 204). In many cases, such as France, organized labour's role in social insurance confers a degree of influence which it might not be able to achieve through wage bargaining systems (Bonoli and Palier 1996). These systems differ, however, in the extent to which the social partners are willing and able to negotiate over broad issues of relevance to the welfare state. At the same time, due to the modest role of public social services, public sector unions are smaller and politically weaker than in the social democratic countries.

The electoral systems of these countries tend to generate multiple veto points. The prevalence of proportional representation (although restricted in some countries) makes single-party governance rare. Federalism (Germany, and increasingly Belgium) and the institutionalized role of the social partners reinforce tendencies towards negotiated reform. A final feature of the political institutional setting deserving emphasis is that all of these countries are 
members of the European Monetary Union and subject to the Maastricht criteria. Given the fiscal circumstances discussed below, this membership may be of considerable importance.

As Kitschelt argues, party systems and public opinion in these countries have also helped to consolidate political support for the welfare state. Social democratic parties are far weaker than in Scandinavia but generally influential. The centre-right in many of these countries have been dominated by Christian democratic parties, which played leading roles in constructing these welfare state models (Van Kersbergen 1995). Despite including factions that are now more critical of extensive social provision, these parties contain significant elements committed to the basic contours of the social contract. Given the scale of these welfare states, it is not surprising that public opinion remains broadly supportive (Svallfors 1997). There is, however, probably less enthusiasm than in Scandinavia, and greater ambivalence where the inequities associated with clientilistic elements of social provision have been most in evidence (Ferrera 1997).

Although they might disagree on the root sources of pressure, there is a fairly wide consensus among commentators that these Continental countries face the greatest demands for adjustment in their core welfare state arrangements (Esping-Andersen 1996c, 1999; Scharpf 1997b). Esping-Andersen has provided an elegant diagnosis of the interlinked problems: high and rising costs associated with generous pensions and subsidized labour market exit; low women's labour force participation; disturbing rates of unemployment among the unskilled (linked to the high fixed labour costs associated with heavy payroll taxes); and low fertility rates.

As in the other regimes, there are powerful complementarities among these elements. In the current economic and social climate, however, these complementarities appear to work in a pernicious direction. High social insurance charges, especially to finance pensions, simultaneously block development of private service employment (by creating high wage floors) and public service employment (by generating fiscal overload). In turn, the unemployment and stagnation of labour force participation rates undercuts the revenue base for pension systems and creates political pressures to subsidize labour market exit through social insurance programmes, especially early retirement and disability schemes. All of these countries responded to initial employment problems by easing entry to various tax-financed paths out of the labour market (Kohli et al. 1991; Ebbinghaus 1999). Employment stagnation and increased reliance on transfers in turn precipitate further increases in payroll taxes. Compounding the difficulties, the blockage of public and private service development jeopardizes the capacity of women to combine labour force participation and child-rearing. This contributes to declining fertility rates, which further imperil the long-term fiscal equilibrium of these systems. Thus, the problem is not just that these countries face major pressures for 
adjustment, but that the possibilities for a 'bad' equilibrium of low employment and low fertility seem very real. In Esping-Andersen's gloomy synopsis, 'these systems find themselves locked into a self-reinforcing negative spiral' (1996c: 68).

The countries in the Continental regime face two quite distinct but potentially complementary reform agendas. First, there is a need to expand employment opportunities, which in the post-industrial world means service employment. This aspiration confronts a series of interconnected obstacles. Several impediments hinder women's efforts to combine paid-work and childrearing (Gornick, Meyers, and Ross 1998). Already very high rates of taxation render the 'social democratic' path of social service employment expansion (which would also facilitate the movement of women into other forms of employment) implausible. High fixed social charges and reservation wages limit private service sector growth, especially for low productivity (and hence low pay) services (Scharpf 1997b).

The second agenda is to achieve cost containment in the main social insurance programmes-pensions, health care, and disability. The Continental systems are transfer-heavy, and in their most extreme form (e.g. Italy, but to a lesser extent France and Germany) approach the status of pensioner states. The combination of demographics and existing commitments generates projections of an even more severe shift in that direction. In most of these countries, health care has also been partly financed from social insurance contributions. These high levels of taxation strain public tolerance while crowding out fiscal space that might allow some social service expansion. As just noted, high social insurance contributions also raise fixed labour costs for firms, undercutting prospects for private sector job growth. Successful pursuit of cost containment would make an important contribution to the task of expanding service employment.

Thus, the Continental welfare states face an imposing list of reform demands, centring on cost containment and on a series of recalibrating adjustments to diminish reliance on payroll taxes, expand employment, and facilitate the efforts of women to combine paid employment with caring responsibilities. Needless to say, this reform agenda confronts formidable political challenges. The major social insurance programmes create powerful vested interests. Serious efforts to reduce expenditures by cutting benefits or tightening eligibility can threaten very broad voting blocs. It is these types of reforms that have prompted large public demonstrations in France, Italy, Germany, the Netherlands, and elsewhere mentioned at the outset of this chapter. Nor is it difficult to point to governments (Juppe in France, several coalitions in the Netherlands, Berlusconi in Italy) which subsequently paid large electoral costs for unpopular retrenchment initiatives. In addition, as shown in Wood's discussion of Germany, efforts to open the labour market for low-paid work may confront challenges from the social partners. It should 
be underscored that the resistance comes not just from unions, but often from employers as well. Having adapted to many aspects of the 'high wagehigh skill' regime and benefited from the welfare state's subsidization of cost-shifting efforts, employers too may resist or only half-heartedly support labour market reforms.

Esping-Andersen (1990) has depicted the new cleavage in the conservative regime as one dividing insiders from outsiders. As in the investigation of the social democratic welfare regime, however, a simple political economy approach is likely to err by exaggerating the political significance of cleavages that run right through the middle of households. 'Outsiders' (e.g. unemployed women and young men) are often economically dependent on insiders, and this may in fact intensify resistance to anything threatening the existing social welfare and employment regime. Indeed, Esping-Andersen's recent acknowledgement (1999: 141) that political mobilization of outsiders was unlikely probably underlies his extremely pessimistic tone about these countries.

Yet a vigorous politics of restructuring is emerging in the Continental regime, captured by the concept (if not all the details) of Blair and Schroder's recent declaration of a 'new middle' ('neue Mitte'). The initial framework outlined in Section I presented the underpinnings for this political depiction. The basic claim made there- that welfare states both generate very strong support and face very severe pressures-applies especially clearly to the Continental regime. The dominant political struggle in the Continental countries is not between insiders and outsiders. Instead, it is between those who seek to create the foundations for a modernized, fiscally and politically viable system of social provision and their opponents, who generally advocate either the preservation of the status quo ('standing pat') or a more radical programme of liberalization ('crashing through').

Thus, the central political issue in Continental Europe during the past two decades has been whether or not particular countries could develop the capacity to initiate and sustain such a 'new middle' coalition of welfare state restructuring. I begin by characterizing the pattern of cross-national outcomes at the end of the 1990s, before turning to the issue of explanation. Regarding outcomes, the consensus view appears to be that the Netherlands represents a clear case of successful reform (the so-called 'Dutch miracle'), with Italy deserving the second prize. By contrast, Belgium, France, and Germany represent the 'frozen welfare state' outcome, showing so far very modest capacities for restructuring. ${ }^{22}$ Particular emphasis is given to the contrast between Dutch success and German failure (Hemerijck and Manow

22 See esp. the country chapters in the Scharpf/Schmidt project and, for an explicitly comparative assessment, Ebbinghaus and Hassel 1999. Levy's (1999) account of the French case has a more optimistic tone, but he acknowledges that his review of policy changes is highly selective, designed to illuminate a particular style of reform rather than to systematically assess the overall trajectory of policy change. 


\section{Coping with Permanent Austerity}

1998). Finally, Austria is often left to one side in these comparisons; its economic performance, and in particular its success in restraining unemployment, has so far generated only modest pressures for restructuring.

As I have argued earlier, establishing the pattern of reform outcomes across countries and over time is an extremely difficult task. Doing so systematically for these cases is well beyond the scope of this essay. Rather than attempting it, I wish to focus briefly on two revealing errors in the consensus judgement. On the one hand, it is overly generous in depicting the achievements of reform coalitions in the Netherlands and Italy; on the other, it exaggerates the extent to which the German welfare state has been locked into a politics of the status quo.

Derided as economic basket cases until recently, both Italy (Ferrera and Gualmini 1999; Baccaro and Locke 1996b) and the Netherlands (Visser and Hemerijck 1997) have since initiated quite substantial restructuring efforts. To deflate the depictions of 'miracles' is not to deny the significance of the reforms carried out in each case. Consider one telling statistic. Policies in place prior to the Italian reforms of 1992, 1996, and 1997 had been projected to generate public pension spending of over 23 per cent of GDP by 2035; current projections estimate that spending will peak at just under 16 per cent (from the current level of about 14 per cent) in 2030 before beginning to decline (Ferrara and Gualmini 1999: table 1). In the Netherlands, policies of labour market reform and negotiated wage restraint have generated a big increase in employment, especially part-time employment. There have been vigorous efforts, so far with uncertain results, to diminish reliance on disability and early retirement 'exit paths' from employment, including a restructuring of disability programmes that greatly enhanced the state's oversight role.

The comparative assessment of reform performance is heavily dependent upon the analyst's choice of time frame. Too often, it is also based on an implicit assumption that the countries being compared are starting from the same point. Yet if one takes the Dutch and Italian cases from 1973, the date usually adopted to demarcate the end of the Golden Age, then one's evaluation diverges from the consensus view. In both cases, conditions first dramatically deteriorated as policy makers resorted to a variety of shortterm expedients, initially including further programmatic expansion, and later reliance on heavy borrowing and subsidized labour market exit. Arguably, the main achievement of the reform initiatives beginning in 1982 in the Netherlands and in the early 1990 s in Italy has been to partially undo the policy damage done in prior years. Despite its jobs 'miracle', Dutch rates of labour force participation are still below the German level. Much of the heavily-touted expansion of women's participation appears to involve very part-time jobs. If one measures the number of hours worked in the paid labour market, rates for Dutch women remain at the very bottom end for 
European Union countries (Daly 1998). Italy, despite notable reforms, continues to have the highest level of pension spending in the affluent world, a very heavy debt load, and alarmingly low rates of women's labour force participation and fertility. How one evaluates these reform efforts turns heavily on one's frame of reference. Their status as 'miracles' rests largely on the contrast with the economic disasters which preceded them.

Adopting a common baseline also suggests a kinder interpretation of the German case, which is widely regarded as an instance of failed adjustment (Manow and Seils 1999). As Wood argues, efforts to reform German labour markets roughly fit the conventional story. In a political system marked by veto points, efforts at reform have generally failed to overcome the resistance of organized interests committed to a deeply embedded labour market regime. Other aspects of the German welfare state, however, have seen rather considerable adjustments, particularly oriented around the goal of cost containment. Giaimo demonstrates that while health care reform came slowly and with difficulty it did come. By the early 1990s, an informal coalition involving the two major parties as well as unions and employers was able to impose significant new cost containment on providers, along with modest user fees. Two major quid pro quos, each an important instance of recalibration, made this painful restructuring acceptable. The reforms reduced inequities among sickness funds (a long-term goal of the unions) and allocated a considerable share of reform savings to a new programme of long-term care insurance.

In the case of pensions, there have been a series of major policy changes since the mid-1970s, all of which strived to control costs. Each successful reform involved extensive negotiations between the major parties and the social partners. ${ }^{23}$ As Alber (1998b) shows, the upshot of all these efforts was not to reduce actual levels of pension spending or pensioner benefits from previous levels, but to essentially eliminate an extensive expansion of pension costs which had been built into previous pension policy. Pension benefits are roughly 30 per cent lower than they would have been if the policies in place in the mid-1970s had not been repeatedly modified. ${ }^{24}$ Approximately half of the savings came from policies of the SPD-FDP government in place until 1982, and about half can be attributed to the Kohl governments which succeeded it. Efforts at cost containment have also taken place in other programmes, although Alber shows that the worst-off (e.g. families dependent on social assistance) have been treated relatively gently.

German restructuring has been discounted not only because in some areas it has been unimpressive (especially labour market reform), but because

${ }^{23}$ In at least one case, employers and unions made a joint submission of their position to the Commission charged with developing the reform.

${ }^{24}$ The German case thus illustrates the magnitude of loss imposition that is possible in pensions policy if policy makers pursue long-term goals, gain broad elite consensus, and do not markedly cut the real benefits of current recipients. 


\section{Coping with Permanent Austerity}

it has been undramatic. Furthermore, the magnitude of change has been partially obscured by the massive shock of German unification, which generated a severe fiscal disequilibrium. Under these exceptional adverse circumstances (which, unlike the case of the Netherlands and Italy were largely unavoidable), however, Germany has arguably done quite well. Germany has managed to keep social expenditure's share of GDP virtually level without sharply reducing benefits for the poor while at the same time introducing some important recalibration of core welfare state practices.

Thus, in my view, the Dutch, Italian, and German cases should all be classified as cases of moderately significant restructuring. Each combines a focus on cost containment with some efforts at recalibration. The reform paths differed, with the Netherlands and Italy first creating large problem loads, prompting economic crises, which then triggered the formation of political coalitions with a clear commitment to sweeping reforms. In Germany, reform has been more continuous and incremental. All these cases contrast with the French and Belgian experiences, where restructuring initiatives have generally been half-hearted.

In all three of the cases of substantial reform, the crucial political dynamic has been the construction of a 'new middle' coalition. The negative dynamic associated with these welfare state regimes prompts calls for fundamental reform. Yet the political configurations are such that serious reform generally requires careful negotiation among all, or at least most, major political actors-not only to surmount veto points, but in order to provide legitimacy for the imposition of losses and assure successful implementation. In the Netherlands and Italy this process has been apparent. In each case, broad centrist coalitions of varying shades have succeeded in convincing key actors, including voters, of the necessity of reform and have introduced major changes. Crucially, in each case vigorous efforts were made to provide reassurances that the ambition of reformers was to save, not destroy, the welfare state. In each case, reforms of social policy concentrated on costly elements (pensions in Italy, disability programmes in the Netherlands) that were both damaging to efficiency and normatively difficult to justify. Given the fiscal difficulties facing each country, opportunities for quid pro quos were limited, but in each country coveted enhancements of underdeveloped aspects of social provision rendered reforms more palatable. Finally, in each case efforts were made to support the most vulnerable; so far, considerable cost containment has not been accompanied by significant increases in poverty.

In Germany as well, successful reform reflects the employment of 'new middle' methods of elite negotiation and mutual legitimation. Both major parties, along with the social partners, have been active participants in sustained dialogue over major structural reforms. What was different in Germany was the informal, intermittent, and compartmentalized character 
of the process. In contrast with the Dutch and Italian cases, reform took place on a policy-by-policy basis rather than through a single, self-described, and well-publicized campaign of overarching reform.

Thus, the central issue for analysts of the conservative regime is to establish the factors determining the viability of such a new political middle. ${ }^{25}$ At this stage, we can probably only begin the process of developing a reasonably convincing set of hypotheses. One can usefully distinguish between factors influencing the demand for a negotiated political response and those factors influencing the capacity of the system to generate that response. On the demand side are, especially, conditions that convince significant actors that 'standing pat' or 'crashing through' are not viable options. Marginalizing those who advocate 'crashing through' will often be easier. Given prominent features of the conservative regime, most important political elements are likely to be sceptical about the desirability of full-fledged liberalization in any event. Even for those who might consider such an outcome desirable in principle, the clear signals of public opinion, or the evident realities of veto points, may be sufficient to generate scepticism about crashing through. There may also be a need for political learning, however, through failed attempts at unilateral liberalization. Berlusconi's negative example appears to have played such a role in Italy, for instance.

Perhaps more critical is the determination by key political actors, especially in unions and left parties, that 'standing pat' is not a viable option. These actors may potentially (although not always) have relatively long time horizons, which allows them to pay attention to issues of policy sustainability (e.g. of old-age pension systems). Crucially, as Fiona Ross (1998) and Jonah Levy (1999) have emphasized, they are also politically positioned to sell reforms as both necessary and intended to revitalize the social contract rather than dismantle it. ${ }^{26}$

What convinces these actors of the need for reform? While a sense of policy imperative is always 'socially constructed', objective circumstances are likely to play a critical role. Well-established and highly valued policies, often the fruits of long political labour, are unlikely to be jettisoned easily. In the words of Maurizio Ferrera, actors must come to believe that 'there

25 Aspects of the following analysis have some relevance for cases in the other regimes as well. Yet as discussed in the conclusion, those configurations vary because they generally face considerably more modest pressures for restructuring, and, in the case of the liberal countries (with the partial exception of Australia), because they have a much lower capacity for negotiated adjustment.

${ }_{25}$ Typical is the rhetoric accompanying German Chancellor Schroder's signing of the 'third way, neue Mitte' document with Tony Blair, which called for major welfare state restructuring including cost containment and labour market reform. In the words of a close aide, 'there is no other way ... If we don't take steps to reform the welfare state, it will collapse.' Another adviser stressed that 'we must gradually convince people there is no alternative'. Financial Times, 9 June 1999, 1, 9. 
is no status quo'27 - that existing arrangements simply cannot be sustained. This is likely to involve both 'social learning' (about what the effects of particular policies will be) and 'political learning' (about the probabilities of achieving alternative policies). Social learning may be driven by focusing events (such as dreadful performance on key indicators) or financial crisis (such as a run on the currency). A more gradual process of learning, in which trial-and-error leads to the discrediting of alternative strategies, may also be crucial (Visser and Hemerijck 1997). Both these processes may be at work, with a period of cumulative learning punctuated by a focusing event that triggers the initiation of reform.

Political learning is likely to involve a similar trial-and-error process as actors explore the viability of alternative strategies. Here a plausible case can be made that political learning is most likely to lead to a 'new middle' outcome where left parties and unions are moderately strong. Moderately strong actors possess resources that are significant enough to place them at the bargaining table, but not so substantial that they can be confident that other actors (a right of centre government or employers) will not try to 'go it alone' if they attempt to exercise a veto. ${ }^{28} \mathrm{This}$, for instance, was clearly the case in both the Netherlands (Visser and Hemerijck 1997) and Italy (Ferrera and Gualmini 1999), where decisions of 'left' and 'centre-left' actors to negotiate and on what terms occurred in the 'shadow' of possible exclusion (Scharpf 1997b). In the Netherlands and Germany centre-right parties have been integral participants in reform efforts. Thus, while Levy and Ross rightly argue that left participation in these restructuring processes is politically critical, they are wrong to portray these initiatives as essentially projects of the political left.

Yet if predispositions for reform among key actors are important, so are conditions which make the 'supply' of such restructuring initiatives possible. Success requires that the relevant social actors and political parties have both the desire and capacity to reach agreements and to make those agreements stick. A great deal of the traditional work on corporatism, which considered similar problems in the field of industrial relations, is relevant here. Two factors, however, appear crucial. The first factor is the quality of links between the social actors and the policy making process, which facilitate the effective implementation of agreements. The second is the ability of elites to maintain sufficient membership support for unpopular initiatives. As Kitschelt argues in this volume, this is an issue not just for unions but for political parties as well. Much is likely to turn on the extent to which potential negotiators find their organizations vulnerable to 'poaching' from competitive

\footnotetext{
${ }^{27}$ Personal communication.

23 Of course, the Continental countries, except France, generally score in the middle range on most scales of left power resources.
} 
organizations (or competing factions within their organization) who could exploit the opportunities created by efforts to impose losses. ${ }^{29}$

At first glance, this list of preconditions seems to imply that the prospects for negotiated reform would be bleak. After all, the conclusion of much of the traditional literature on corporatism was that breakdown was likely in the absence of relatively high levels of organizational concentration. Yet in fact, as Rhodes shows, there has been a rather striking sprouting of social pacts in recent years, even (or especially) in settings that might not have been considered fertile soil. In the current climate, those seeking a negotiated solution possess two significant advantages. First, in line with the analysis offered in Figure 13.1, they are likely to straddle the political space occupied by the pivotal voter. This position gives these elites considerable leverage, especially, as Kitschelt argues, if they are willing to trade off some erosion of membership support for sustained influence over policy.

The second advantage, as Jonah Levy has eloquently argued, is the possibility for turning 'vice into virtue'. In all these welfare states, Levy notes, there are opportunities to 'target inequities within the welfare system that are simultaneously a source of either economic inefficiency or substantial public spending. ... [I]nherited welfare vices can be manipulated so as to soften or even obviate the supposedly ineluctable tradeoff between efficiency and equity' (Levy 1999: 240). In the terms employed in this essay, restructuring packages need not be limited to cost containment and re-commodification. They may also include substantial efforts at recalibration. As has been noted, the need for updating in many of these systems is evident, which may facilitate legitimation while generating crucial fiscal resources. When orchestrated through a broad, centrist coalition (formal or informal), which has credibility in claiming that the goal is restructuring rather than dismantling and that there are no viable alternatives, this can be a genuinely formidable political formula. In practice, the Dutch, German, and Italian cases all reveal a modest but very real possibility for the negotiated restructuring of conservative welfare states.

The argument presented in this section is summarized in Table 13.2. The three worlds of welfare capitalism differ in critical respects, which generate quite different political dynamics of welfare state restructuring. Most crucially, the different regimes vary in both the scope of support for the

${ }^{29}$ Both France and Belgium fall short in these respects. And unlike the case in the liberal regimes, the capacity of these two countries to concentrate political authority was not sufficient to generate major reforms. As Bonoli notes, French political authority is concentrated. In Belgium, governments ruling by decree were able for some time to exploit a similar concentration of formal authority (Scharpf 1999). In both cases, however, efforts to impose rather than negotiate reforms ultimately floundered in the face of widespread political opposition and the inability to implement key changes without consent. This underscores my earlier suggestion that the effects of concentrated political authority will be different within the conservative regime than they are in the liberal one. 
Coping with Permanent Austerity

TABLE 13.2. Three worlds of welfare state reform

\begin{tabular}{|c|c|c|c|}
\hline & Liberal & Social democratic & Conservative \\
\hline $\begin{array}{l}\text { Political Support for } \\
\text { Welfare State }\end{array}$ & Moderate & High & High \\
\hline $\begin{array}{l}\text { Adjustment } \\
\text { Pressures }\end{array}$ & Moderate & Moderate & High \\
\hline Reform Agenda & $\begin{array}{l}\text { Re-commodification/ } \\
\text { cost containment }\end{array}$ & $\begin{array}{l}\text { Cost containment/ } \\
\text { recalibration } \\
\text { (rationalization) }\end{array}$ & $\begin{array}{l}\text { Cost containment/ } \\
\text { recalibration } \\
\text { (updating) }\end{array}$ \\
\hline Line of Conflict & $\begin{array}{l}\text { Neoliberal } \\
\text { retrenchment vs. } \\
\text { compensated } \\
\text { commodification }\end{array}$ & $\begin{array}{l}\text { No dominant } \\
\text { cleavage } \\
\text { Negotiated, } \\
\text { incremental } \\
\text { adjustment }\end{array}$ & $\begin{array}{l}\text { 'Stand Pat' vs. } \\
\text { Negotiated } \\
\text { Reform }\end{array}$ \\
\hline $\begin{array}{l}\text { Distinct Key } \\
\text { Variables }\end{array}$ & $\begin{array}{l}\text { Concentration of } \\
\text { political authority }\end{array}$ & & $\begin{array}{l}\text { Vulnerability of } \\
\text { centrist reform } \\
\text { organizations } \\
\text { to 'poaching' }\end{array}$ \\
\hline
\end{tabular}

welfare state and in the scale and nature of adjustment pressures. In the liberal welfare states, adjustment pressures have been moderate, but so has been support for the existing welfare state. In the social democratic welfare states popular support is widespread and adjustment pressures have also been moderate. In the conservative welfare states, popular support of the existing regime is strong but so are pressures for adjustment.

These differences in the depth of popular support and the scale and nature of pressures in turn generates different political alignments, different plausible reform trajectories, and (somewhat more speculatively) different critical variables in the restructuring process. In short, there is not a single 'new politics' of the welfare state, but different politics in different configurations. In the liberal world reform focuses on cost containment and re-commodification, with the crucial divide between those advocating thoroughgoing neoliberal retrenchment and those seeking a more consensual and compensatory solution. In a context where support for social provision is relatively thin and the electoral/legislative arena plays a dominant role, partisan control of government and the degree to which institutions concentrate political authority become critical factors. In the social democratic world, the focus of reform is on cost containment and recalibrations, which aim at rationalizing programmes to enhance performance in achieving established goals. On the whole, reform has been negotiated, consensual, and incremental. In the conservative world, reform has centred on cost containment and recalibration, with a heavy emphasis on updating 'old' programmes to meet new demands. Neoliberal retrenchment is not a viable option, so politics centres on efforts to construct a viable reform coalition. The structure of 
interest intermediation and party systems-in particular, whether they allow reformers to overcome their fears of poaching-are crucial.

Two final observations about this summary statement underscore key features of the contemporary politics of social policy. The first, as indicated in Table 13.1, is that a critical factor in structuring reform in all three configurations is the severity of economic pressures. Intense disequilbria have a major impact on reform dynamics. These disequilbria may or may not stem primarily from 'globalization', but it is important to stress that it is not politics alone that determines how or when countries undertake significant reform initiatives. By implication, the future fate of mature welfare states is likely to be dependent upon the economic performance of the particular countries to which they are joined. This volume has offered grounds for scepticism about the deleterious economic effects of extensive social provision. However, if these negative effects are as severe and persistent as some critics allege, more wide-ranging reforms seem likely.

The second observation is that while reform agendas vary quite substantially across regime types, all of them place a priority on cost containment. This shared emphasis reflects the onset of permanent austerity. Welfare states are not being dismantled. Efforts to achieve recalibration can generate interesting innovations and even extensions of social provision. Yet everywhere, such adjustments occur in a context where the control of public expenditure is a central if not dominant consideration. The core structures of most welfare states are not in jeopardy. Nonetheless, the contemporary climate remains a harsh one for efforts to improve social provision for the vulnerable or to address newly recognized risks. 


\section{References}

Alber, Jens (1998b). 'Recent Developments in Continental Welfare States: Do Austria, Germany, and the Netherlands Prove to be Birds of a Feather?'. Paper presented to 14th World Congress of Socilogy, Montreal, July 1998.

ANDERSON, Karen M. (1998). 'Organized Labor, Policy Feedback, and Retrenchment in Swedish Pension and Unemployment Insurance'. Paper prepared for the 11th International Conference of Europeanists, Council of European Studies. Baltimore, 26-28 Feb.

ARTHUR, BRIAN (1994). Path Dependence and Increasing Returns in Economics. Ann Arbor: University of Michigan Press.

Baccaro, Lucio, and Locke, Richard M. (1996b). 'Public Sector Reform and Union Participation: The Case of the Italian Pension Reform'. Sloan School of Management Working Paper, No. 3922-96-BPS.

BenNer, MATs, VAD, ToRBEN, and Schludi, MARTin (1999). 'Sweden and Denmark: Changing Places in Defense of the Welfare State'. Paper delivered at the conference on 'The Adjustment of National Employment and Social Policy to Economic Internationalization', Ringberg Castle, Germany, 17-20 Feb. 1999.

BonOli, Giuliano and Palrer, Bruno (1996). 'Reclaiming Welfare: The Politics of French Social Protection Reform'. South European Society and Politics, 1: 24059.

- Vic, George, and TAYLOR-Gooby, Peter (forthcoming). European Welfare Futures: Towards a Theory of Retrenchment. Cambridge: Polity Press.

Brady, David W, and Volden, Craig (1998). Revolving Gridlock: Politics and Policy from Carter to Clinton. Boulder, Colo.: Westview Press.

CASTLEs, Francis G. (1996). 'Needs-Based Strategies of Social Protection in Australia and New Zealand', in G. Esping-Andersen (ed.), Welfare States in Transition: National Adaptations in Global Economies. London: Sage, 88-115.

- and Mrtchell, Deborah (1993). 'Three Worlds of Welfare Capitalism or Four?', in Francis G. Castles (ed.), Families of Nations: Public Policy in Western Democracies. Brookfield, Vt.: Dartmouth.

- and Pierson, Christopher (1996). 'A New Convergence? Recent Policy Developments in the United Kingdom, Australia, and New Zealand'. Policy and Politics, 24 (3): 233-45.

Clayton, RichaRD, and Pontusson, Jonas (1998). 'Welfare-State Retrenchment Revisited: Entitlement Cuts, Public Sector Re-structuring, and Inegalitarian Trends in Advanced Capitalist Societies'. World Politics, 51 (1): 67-98.

Collier, David, and Levitsky, Steven (1997). 'Democracy with Adjectives: Conceptual Innovation in Comparative Research'. World Politics, 49 (3): 430-51.

DALY, MARY (1998). 'Between Home and Work: Women and Labour Market Participation in International Comparison'. Unpublished manuscript.

DAVID, PAUL (1985). 'CLIO and the Economics of QWERTY'. American Economic Review, 75 (2): 332-7.

EBBinghaus, BERnhard (1999). 'Any Way Out of "Exit from Work"? Reversing the Entrenched Pathways of Early Retirement in Europe, USA and Japan'. Contribution to the MPI Project on 'Adjustment to Economic Internationalization'. 
- and HASSEL, ANKE (1999). 'The Role of Tripartite Concertation in the Reform of the Welfare State'. Transfer, 5 (1-2): 64-81.

Esping-Andersen, Gøsta (1985). Politics Against Markets. Princeton: Princeton University Press.

- (1990). The Three Worlds of Welfare Capitalism. Princeton: Princeton University Press.

(1996a). 'After the Golden Age? Welfare State Dilemmas in a Global Economy', in G. Esping-Andersen (ed.), Welfare States in Transition: National Adaptations in Global Economies. London: Sage, 1-31.

_ (1996c). 'Welfare States Without Work: The Impasse of Labour Shedding and Familialism in Continental Social Policy', in G. Esping-Andersen (ed.), Welfare States in Transition: National Adaptations in Global Economies. Thousand Oaks, Calif: Sage Publications, 66-87.

- (1999). Social Foundations of Postindustrial Economies. Oxford: Oxford University Press.

Ferrera, Maurizio (1996). 'The Southern Model of Welfare in Social Europe'. Journal of European Social Policy, 6 (1): 17-37.

- (1997). 'The Uncertain Future of the Italian Welfare State', in M. Bull and M. Rhodes (eds.), Crisis and Transition in Italian Politics. London: Frank Cass, 23149.

and Gualmini, Elisabetta (1999). 'Italy: Rescue From Without?'. Paper presented to the MPI Project Meeting in Ringbergen.

Flora, Peter (1989). 'From Industrial to Postindustrial Welfare State?'. Annals of the Institute of Social Science, special issue (Institute of Social Science, Tokyo).

Giamo, Susan M. and Manow, PhILIP (1999). 'Welfare State Adaptation or Erosion? The Case of Health Care Reform in Britain, Germany, and the United States. Comparative Political Studies, Dec.

Golden, Miriam, Wallerstein, Michael, and Lange, Peter (1999). 'Postwar Trade-Union Organization and Industrial Restructuring in Twelve Countries', in Kitschelt, Lange, Marks, and Stephens, Change and Continuity in Contemporary Capitalism.

Gornick, Janet, Meyers, Marcia K., and Ross, Katherin E. (1998). 'Public Policies and the Employment of Mothers: A Cross-National Study'. Social Science Quarterly, 79 (1) (Mar.): 35-54.

Gotring, Ulrike, Haug, Karin, and Hinrichs, Karl (1994). 'The Long Road to Long-Term Care Insurance in Germany'. Journal of Public Policy, 14 (3): 285309.

HACKER, JACOB (1998). 'The Historical Logic of National Health Insurance: Structure and Sequence in the Development of British, Canadian, and U.S. Medical Policy'. Studies in American Political Development, 12 (1): 57-130.

HALL, PETER (1999). 'The Political Economy of Europe in an Era of Interdependence', in Kitschelt et al., Continuity and Change.

HemeriJCK, ANTon C. and Manow, Philip (1998). 'The Experience of Negotiated Social Policy Reform in Germany and the Netherlands'. Max Planck Institute, Cologne, June. 
Hills, John (1998). 'Thatcherism, New Labour and the Welfare State'. Center for the Analyses of Social Exclusion Paper, No. 13, London School of Economics.

Howard, Christopher (1997). The Hidden Welfare State: Tax Expenditures and Social Policy in the United States. Princeton: Princeton University Press.

HUBER, EvelyNe and STEPHENS, JoHN D. (1998). 'Internationalization and the Social Democratic Model'. Comparative Political Studies, 31 (3) (June): 353-97.

IverSEN, Torben (1998a). "The Choices for Scandinavian Social Democracy in Comparative Perspective'. Oxford Review of Economic Policy, 14 91): 59-75.

- and WREN, ANNE (1998). 'Equality, Employment and Budgetary Restraint: The Trilemma of the Service Economy'. World Politics, 50 (4): 507-46.

Judis, JoHn B. (1995). 'Abandoned Surgery: Business and the Failure of Health Care Reform'. American Prospect, 2 (Spring): 65-73.

Kitschelt, Herbert, Lange, Peter, Marks, Gary, and Stephens, John D. (1999a). 'Conclusion. Convergence and Divergence in Advanced Capitalist Democracies', in Herbert Kitschelt, Peter Lange, Gary Marks, and John Stephens (eds.), Continuity and Change in Contemporary Capitalism. Cambridge: Cambridge University Press, 427-60.

New York: Cambridge University Press.

Kohli, Martin, Rein, Martin, Guillemard, AnNe-Marie and van Gunsteren, HERMAN (1991). Time for Retirement: Comparative Studies of Early Exit from the Labor Force. Cambridge: Cambridge University Press.

KoRPI, WALTER (1999). 'Faces of Inequality: Gender, Class and Inequalities in Different Types of Welfare States'. Unpublished manuscript, Swedish Institute for Social Research.

KRASNER, STEPHEN D. (1989). 'Sovereignty: An Institutional Perspective', in James Caparaaso (ed.), The Elusive State. Thousand Oaks, CA: Sage Publications, 6996.

KReHbiel, KeIth (1998). Pivotal Politics: A Theory of U.S. Lawmaking. Chicago: University of Chicago Press.

Kuhnle, Stein, and Eitrheim, Pal (1999). 'The Scandinavian Model: Trends and Perspectives'. EUI European Forum Seminar Paper WS/23.

LeVY, Jonah (1999). 'Vice into Virtue? Progressive Politics and Welfare Reform in Continental Europe'. Politics \& Society, 27 (2): 239-73.

LinDBlom, ChaRLes E. (1977). Politics and Markets: The World's Political-Economic Systems. New York: Basic Books.

LINDBOM, ANDERS (1999). 'Dismantling the Social Democratic Welfare Model? Has the Swedish Welfare State Lost Its Defining Characteristics?'. Paper Presented to Workshop 26, European Consortium for Political Research, Mannheim, Mar.

MaNow, PHILIP, and SEILS, Eric (1999). 'Adjusting Badly: The German Welfare State, Structural Change and the Open Economy', forthcoming in Fritz W. Scharpf and Vivien A. Schmidt (eds.), From Vulnerability to Competitiveness: Welfare and Work in the Open Economy. New York: Oxford University Press.

MARES, IsABELA (1998). 'Negotiated Risks: Employers and Welfare State Development'. Ph.D. thesis. Harvard University. 
Myles, John (1997). 'How to Design a "Liberal" Welfare State: A Comparison of Canada and the United States'. Paper prepared for the Conference on 'Models of: Capitalism and Latin American Development', Chapel Hill, University of North Carolina, May.

(1999). 'The Maturation of Canada's Retirement Income System: Income Levels, Income Inequality and Low Income among the Elderly'. Unpublished manuscript.

— and Pierson, Paul (1997). 'Friedman's Revenge: The Reform of "Liberal" Welfare States in Canada and the United States'. Politics and Society, 25: 443-72. North, Douglass C. (1990). Institutions, Institutional Change, and Economic Performance. Cambridge: Cambridge University Press.

O'Connor, Julia S., Orloff, Ann Shola, and Shaver, Sheila (1999). States, Markets, Families: Gender, Liberalism and Social Policy in Australia, Canada, Great Britain and the United States. Cambridge: Cambridge University Press.

OFFe, Claus (1991). 'Smooth Consolidation in the West German Welfare States', in Frances Fox Piven (ed.), Labor Parties in Postindustrial Societies. New York: Polity Press, 124-46.

Orloff, Ann Shola (1993). 'Gender and the Social Rights of Citizenship: The Comparative Analysis of Gender Relations and Welfare States'. American Sociological Review, 58: 303-28.

Pierson, Paul (1994). Dismantling the Welfare State? Reagan, Thatcher and the Politics of Retrenchment. Cambridge: Cambridge University Press.

_ (1996). 'The New Politics of the Welfare State'. World Politics, 48 (2): 14379.

(1998). 'Irresistible Forces, Immovable Objects: Post-Industrial Welfare States Confront Permanent Austerity'. Journal of Eurapean Public Policy, 5 (4): 53960.

(2000). 'Increasing Returns, Path Dependence, and the Study of Politics! American Political Science Review, 94 (2), 251-67.

and Weaver, Kent (1993). 'Imposing Losses in Pension Policy', in Kent Weaver and Bert Rockman (eds.), Do Institutions Matter? Government Capabilities in the United States and Abroad, Washington, DC: Brookings Institution.

Ragin, Charles C. (1987). The Comparative Method: Moving Beyond Qualitative and Quantitative Strategies. Berkeley: University of California Press.

Ross, Fiona (1998). 'A Framework for Studying Unpopular Policies: Partisan Possibilities, Institutional Liabilities and the Anti-State Agenda'. Unpublished manuscript.

ROTHSTEIN, Bo (1998a). 'The Future of the Universal Welfare State-An Institutional Approach'. Unpublished manuscript.

- (1998b). Just Institutions Matter: The Moral and Political Logic of the Universal Welfare State. Cambridge: Cambridge University Press.

ScharPF, FrITz W. (1987). Sozialdemokratische Krisenpolitik in Europa. Frankfurt: Campus.

(1997b). 'Employment and the Welfare State: A Continental Dilemma'. Max Planck Institute Working Paper, 7. 


\section{Mimeo.}

Schwartz, HermaN (2000). 'Internationalization and Two Welfare States: Australia and New Zealand', in Fritz Scharpf and Vivien Schmidt (eds.), Welfare and Work in the Open Economy, ii. Diverse Responses to Common Challenges. Oxford: Oxford University Press.

- and Rhodes, MARTIN (1999). 'Internationalization and the Liberal Welfare States: The UK, Australia and New Zealand'. Contribution to MPI Project on Adjustment to Internationalization.

Shalev, Michael (ed.) (1996). The Privatization of Social Policy? Occupational Welfare and the Welfare State in America, Scandinavia and Japan. New York: St Martin's.

_- (1999). 'Limits of and Alternatives to Multiple Regression in Macro-Comparative Research'. European University Institute, European Forum Paper WS/80, May.

Soskice, David (1999). 'Divergent Production Regimes: Coordinated and Uncoordinated Market Economies in the 1980s and 1990s', in Kitschelt et al. (eds.), Continuity and Change, 101-34.

STEPHENS, JoHN D. (1996). 'The Scandinavian Welfare States: Achievements, Crisis and Prospects', in Esping-Andersen (ed.), Welfare States in Transition, 32-65.

- HubER, EVELYNE, and RAY, LEONARD (1999). 'The Welfare State in Hard Times', in Kitschelt et al. (eds.), Continuity and Change, 164-93.

Svallfors, Stefan (1995). 'The End of Class Politics: Structural Cleavages and Attitudes to Swedish Welfare Policies'. Acta Sociologica, 38: 53-74.

- (1997). 'Worlds of Welfare and Attitudes to Redistribution: A Comparison of Eight Western Nations'. European Sociological Review, 13 (3): 283-304.

Swenson, Peter (1991b). 'Labor and the Limits of the Welfare State: The Politics of Intraclass Conflict and Cross-Class Alliances in Sweden and West Germany'. Comparative Politics, 23 (4) (July): 379-400.

Thelen, Kathleen (1999). 'Why German Employers Cannot Bring Themselves to Dismantle the German Model', in T. Iversen, J. Pontusson, and D. Soskice (eds.), Unions, Employers and Central Banks: Wage Bargaining and Macro-economic Regimes in an Integrating Europe. New York: Cambridge University Press (forthcoming).

Tsebelis, George (1995). 'Decision Making in Political Systems: Veto Players in Presidentialism, Parliamentarism, Multicamerialism and Multipartyism'. British Journal of Political Science, 25: 289-325.

VAN KERSBERGEN, KEES (1995). Social Capitalism. London: Routledge.

YISSER, JELLE and HeMERIJCK, ANTON (1998). 'A Dutch Miracle': Job Growth, Welfare Reform and Corporatism in the Netherlands. Amsterdam: Amsterdam University Press.

Weaver, R. Kent (1986). 'The Politics of Blame Avoidance'. Journal of Public Policy, 6: 371-98.

- (1998). 'The Politics of Pensions: Lessons from Abroad', in R. Douglas Amold, Michael Graetz, and Alicia Munnell (eds.), Framing the Social Security Debate; Values, Politics and Economics. Washington, DC: National Academy of Social insurance, 183-228. 
WILENSKy, Harold (1981). 'Leftism, Catholicism, and Democratic Corporatism: The Role of Political Parties in Recent Welfare State Development', in Peter Flora and Amold Heidenheimer (eds.), The Development of Welfare States in Europe and America. New Brunswick: Transaction, 345-82. 